\title{
IMÁGENES EMBLEMÁTICAS PARA EL ADOCTRINAMIENTO REGIO: LOS SERMONES DEL PREDICADOR REAL JOSÉ BARCIA EN LA Corte de Carlos II
}

\author{
José Javier Azanza López \\ Universidad de Navarra
}

RESUMEN: Entre 1687 y 1691, el predicador real José Barcia (Málaga, 1643-Cádiz, 1695) pronunció un conjunto de sermones a Carlos II y a la familia real en escenarios como la Capilla Real del Alcázar, San Jerónimo o las Descalzas Reales. Sin dejar de tener un marcado carácter doctrinal, la predicación de Barcia supone un intento por trazar la personalidad del rey, abordando cuestiones como la concepción providencialista de la monarquía hispana, la conducta virtuosa como garante del trono, la tan ansiada descendencia real, o la certeza de la muerte y su poder igualador. Se sirve para ello de imágenes emblemáticas tomadas de Alciato, Valeriano, Picinelli, Solórzano Pereira o Van Haeften; y, sobre todo, de las Empresas Políticas de Saavedra Fajardo, en su empeño por hacer de Carlos II un nuevo príncipe político-cristiano.

Palabras clave: José Barcia, Carlos II, Capilla Real, oratoria sagrada, emblemática.

AbSTRACt: The Royal preacher José Barcia (Málaga, 1643-Cádiz, 1695) preached between 1687 and 1691 several sermons to Charles II and the Royal Family in the Royal Chapel of the Alcazar, San Jerónimo or the Descalzas Reales. Always maintaining a doctrinal focus, Barcias's preaching represented an attempt to trace the personality of the monarch, with concepts such as the providential nature of the Spanish monarchy, virtuous conduct as a condition for keeping the throne, the long-awaited heir, or the certainty of death and its levelling nature. For this he uses images taken from Alciato, Valeriano, Picinelli, Solórzano Pereira or Van Haeften; and, above all, from the Empresas Politicas of Saavedra Fajardo, in his endeavour to make Charles II a new political Christian prince. 
Keywords: José Barcia, Charles II, Royal Chapel, Sacred Oratory, Emblematic Images.

\section{José BARCIA y ZAMBRANA: BREVE SEMBLANZA BIOGRÁfiCA}

J osé Barcia y Zambrana nació en Málaga en 1643, en el seno del matrimonio formado por Antonio Juan Barcia, natural de la localidad pontevedresa de Geve, y Teresa de Zambrana, originaria de Málaga. ${ }^{1}$ En las Escuelas de la Sagrada Compañía comenzó su temprana vocación, y demostró muy pronto su capacidad para el latín y la retórica; y aunque estuvo a punto de ingresar en el convento de Trinitarios, finalmente se trasladó a Granada, en cuyo Colegio del Sacromonte cursó estudios de Teología.

Tras doctorarse, el obispo Antonio de Piña Hermosa, que rigió la diócesis de Jaén entre 1664 y 1667, lo nombró teólogo, examinador y visitador de su obispado. Pero fue en el Sacromonte granadino donde inició su verdadero cursus honorum, pues en 1670 fue nombrado canónigo de su iglesia colegial, ocupando además la Cátedra de Sagradas Escrituras; cinco años más tarde era ya rector del Colegio, ${ }^{2}$ y alcanzará también el cargo de visitador general del arzobispado. En la capital andaluza residía cuando tuvo lugar el terremoto del 9 de octubre de 1680, del que deja testimonio vivo y directo en un sermón de acción de gracias dedicado al Santo Cristo de la Columna del Hospital del Corpus Christi. ${ }^{3}$

Inclinado a la predicación y dirección espiritual de las almas, se distinguió durante estos años en las misiones populares en distintos pueblos y ciudades de Granada y Sevilla; ${ }^{4}$ y tuvo también su primer contacto con la Corte, donde «cogió grandes frutos de reformación de costumbres», según el testimonio del trinitario Juan Muñoz de la Cueva. Todo ello llegó a conocimiento del cardenal

1. Fueron sus abuelos paternos Juan Barcia y María de Arriba (Geve), y los maternos Juan García Zambrana (Bujalance) e Isabel Pérez (Vélez-Málaga). José-SAntiago Crespo Pozo: Blasones y linajes de Galicia, t. II, Editorial de los Bibliófilos Gallegos, Santiago de Compostela, 1957, 164-165. Algunos datos biográficos sobre José Barcia son recogidos igualmente por M. ${ }^{a}$ CARMEN MOLINA GutiérREZ: «Barcia y Zambrana, José», Diccionario de Escritores de Málaga y su provincia, Editorial Castalia, Madrid, 2002, 98-99.

2. Así figura en el certamen poético celebrado en dicho año por el colegio granadino con motivo de la colocación en su capilla de la nueva imagen de su patrono, san Dionisio Areopagita, y del que José Barcia fue uno de sus jueces. INMACULADA OsUnA: «Justas poéticas en Granada en el siglo Xvir: materiales para su estudio», Criticón, n. ${ }^{\circ}$ 90, 2004, 71.

3. Despertador Christiano de Sermones Doctrinales, t. III, 444-458 (ed. Cádiz, 1694). Sobre este acontecimiento, véase Pedro Rueda Ramírez y Manuel Fernández Chaves: «El terremoto como noticia: relaciones de sucesos y otros textos del temblor de 1680», Estudios sobre el Mensaje Periodístico, n. ${ }^{\circ} 14$, 2008, 581-604.

4. A dicha labor alude Javier Burrieza SÁnchez: «Ciudades, misiones y misioneros jesuitas en la España del siglo XVIII», Investigaciones Históricas, n. ${ }^{\circ}$ 18, 1998, 77. 
Luis Fernández de Portocarrero, arzobispo de Toledo entre 1677 y 1709, quien en 1685 lo promovió a la capital castellana y lo nombró canónigo de su Santa Iglesia Primada. ${ }^{5}$ En prueba de gratitud, José Barcia le dedicó (dedicatoria compartida con Nuestra Señora del Sagrario venerada en su capilla de la seo toledana) el tomo II de su Despertador Christiano Quadragessimal de Sermones Doctrinales.

Pese a su renuencia a recibir cargos -su humildad lo llevó a renunciar a las sedes de Astorga, Canarias y Granada-, fue prior de la colegiata de Santa María de Sar, dignidad de la santa metropolitana iglesia de Compostela. Y durante su etapa toledana fue nombrado predicador real, título que recibían quienes «tienen a su cargo predicar al rey la palabra evangélica en su Capilla Real, o adonde se les ordena». ${ }^{6}$ Para acceder a tal honor y responsabilidad tuvo que verificar informaciones de pureza de sangre, vida y costumbres, proceso que se llevó a cabo en el mes de enero de 1689 y que dio lugar al correspondiente expediente personal. ${ }^{7}$ Dirigió la instrucción Antonio de Benavides y Bazán, patriarca de las Indias Occidentales y arzobispo de Tiro, en quien, como capellán mayor de la Capilla Real, recaían las competencias de elevar al rey las propuestas de candidatos para ser nombrados predicadores reales. ${ }^{8}$ Este comisionó para el examen de testigos fidedignos por medio del interrogatorio de preguntas a Carlos Muñoz de Castillblanc, capellán de honor de Su Majestad y administrador del Real Hospital del Buen Suceso en la Corte; en total fueron doce los declarantes, ocho naturales de Málaga, tres de Granada, y el último canónigo de Toledo (Francisco Cervantes), todos los cuales dieron fe de la calidad del pretendiente. A la vista de la genealogía, pruebas y declaraciones, Muñoz de Castillblanc elaboró su informe favorable el 30 de enero («es D. Joseph de Barcia muy digno de que Su Majestad se sirva de él por su predicador real»); y un día más tarde, el patriarca de las

5. De ello nos da noticia el canónigo toledano Cristóbal Ruiz al indicar que «su doctrina mueve con valentía, y su predicación persuade y exhorta, como felizmente se experimenta en esta Imperial Ciudad, desde que la grandeza, santo celo, e incomparable cuidado del mayor lustre de su Santa Iglesia, y del mayor bien de sus súbditos, movió al eminentísimo Señor Don Luis Manuel Fernández Portocarrero, Arzobispo de Toledo, mi Señor, para trasladarle del Monte Santo de Granada, al Candelero de su muy Santa Iglesia Primada». Aprobación del tomo II del Despertador Christiano Quadragessimal de Sermones Doctrinales, por el Dr. D. Cristóbal Ruiz Franco de Pedrosa, canónigo de la Santa Iglesia de Toledo. En Toledo, a 15 de febrero de 1686. Al período toledano se refieren igualmente los Apuntes biográficos de diversas personas, cartas y otros documentos, recopilados por el compositor español del siglo XIX Francisco Asenjo Barbieri.

6. Antonio Álvarez-Ossorio Alvariño: «La sacralización de la dinastía en el púlpito de la Capilla Real en tiempos de Carlos II», Criticón, n. ${ }^{\circ}$ 84-85, 2002, 313-332; y «Facciones cortesanas y arte del buen gobierno en los sermones predicados en la Capilla Real en tiempos de Carlos II», Criticón, n. . 90, 2004, 99-123.

7. Archivo General de Palacio. Expedientes personales. Caja 7.750. Exp. n. ${ }^{\circ}$ 7. Expediente personal de José Barcia y Zambrana.

8. En efecto, al capellán mayor correspondía la designación de candidatos a predicador real y de oradores encargados de pronunciar el sermón en las fiestas señaladas. Durante el reinado de Carlos II, el puesto de capellán mayor y limosnero fue desempeñado por el patriarca de las Indias, arzobispo de Tiro, práctica que se había establecido a comienzos del siglo xviI y se consolidó al comenzar el reinado de Felipe IV. Antonio de Benavides y Bazán fue patriarca de las Indias Occidentales entre 1679 y 1690. Álvarez-Ossorio Alvariño, «La sacralización de la dinastía en el púlpito de la Capilla Real...», 314; y «Facciones cortesanas y arte del buen gobierno...», 101. 
Indias ordenaba entregar a Barcia el despacho acostumbrado para que en la Secretaría de la Cámara se le expidiese el título de predicador real.

Resulta de interés para el tema que aquí abordamos comprobar cómo la relación de Barcia con la familia real debió de ser cercana, incluso con antelación a su nombramiento como predicador real, por cuanto ya en 1687 y $1688-$ si nos atenemos a las fechas que él mismo nos proporciona- había predicado sermones en la Corte en fiestas señaladas, suponemos que por voluntad del propio Antonio de Benavides y Bazán. Tras acceder al cargo, la proximidad se concreta no solo en la trascendencia de las homilías regias, sino también en la dedicatoria de varios sermonarios tanto a la reina madre Mariana de Austria, a quien se dirige en términos de «Diamante Austriaco» $\mathrm{y}$ «Águila Austriaca» (comparaciones que establece a partir del Mundus Symbolicus de Filippo Picinelli), como al propio Carlos II, al que equipara con la luz de la Creación, destinado a iluminar con su patrocinio la perfección de María para ejemplo de las almas. ${ }^{9}$ En todos los casos concluye su dedicatoria dirigiéndola «a los reales pies de V. Majestad, su más humilde y reconocido capellán, y siervo».

Tras su período como canónigo y magistral de la catedral de Toledo, la última etapa de Barcia comienza con su nombramiento como obispo de Cádiz y de Algeciras, ${ }^{10}$ del cual nos da noticia en el prólogo a su Despertador Christiano Marial, al significar que «al imprimir este tomo me han sobrevenido cuidados mayores, cuales son los Pastorales». El 27 de agosto de 1691 fue promovido a la sede episcopal gaditana, en sustitución de Antonio de Ibarra. Su nombramiento debe ponerse en relación con la asistencia espiritual prestada a los miembros de la familia real, por cuanto no resulta extraño que capellanes, confesores y predicadores de los reyes accediesen con relativa facilidad al episcopado, mecanismo de ascenso personal que constituía a su vez uno de los pocos elementos capaz de trasladar los intereses del poder central a la periferia; desde esta perspectiva, el obispado debe entenderse no solo como un cargo eclesiástico, sino como una de las vías más importantes a la hora de estructurar el estado moderno español. ${ }^{11}$

9. A la reina Mariana de Austria dedica el Despertador Christiano Divino y Eucharistico, de varios sermones de Dios Trino, y Uno (1689), y el Despertador Christiano Eucharistico de varios sermones del Santissimo Sacramento del Altar (1690). Y al rey Carlos II, el Despertador Christiano Marial de varios sermones de Maria Santisima, este último ya en 1692, siendo obispo de Cádiz.

10. Sobre la diócesis de Cádiz y la labor de sus obispos en el siglo XviI, véase ARTURo MorgADo GARCía: El estamento eclesiástico y la vida espiritual en la Diócesis de Cádiz en el siglo XVII, Servicio de Publicaciones de la Universidad, Cádiz, 1996; y Maximiliano Barrio Gozalo: «Aspectos socioeconómicos de un grupo privilegiado del Antiguo Régimen. Los obispos de Cádiz (1556-1833)», Trocadero. Revista de Historia Moderna y Contemporánea, n. ${ }^{\circ}$ 12-13, 2000-2001, 100-121.

11. Así lo constata para el caso andaluz Maximiliano Barrio Gozalo: «Perfil socioeconómico de una élite de poder, V: Los obispos de Andalucía (1600-1840)», Anthologica Annua, n. 34, 1987, 71. Véase también Fernando Negredo del Cerro: Los predicadores de Felipe IV. Corte, intrigas y religión en la España del Siglo de Oro, Editorial Actas, Madrid, 2006, 41 y 73-77; y, del mismo autor, «Servir al rey y servirse del rey. Los predicadores regios en el primer tercio del siglo XVII», Servir al rey en la monarquía de los Austrias. Medios, fines y logros del servicio al soberano en los siglos XVI y XVII (ed. Alicia Esteban Estríngana), Sílex, Madrid, 2012, 361-382, donde asevera que el servicio al rey desde la Real Capilla era la plataforma idónea para recibir prebendas y progresar económica y socialmente. 
Su marcha a Cádiz no supuso un distanciamiento definitivo de la familia real; tenemos constancia de que la reina madre y su hijo le escribieron pidiéndole información acerca del modo en que se celebraba el rosario en las calles de la ciudad andaluza, y que el prelado respondió enviándoles los libros que había escrito sobre este asunto el capuchino fray Pablo de Cádiz -hijo del cónsul de la república genovesa en Cádiz, Juan Francisco Patrón-, a resultas de lo cual Carlos II ordenó que en la Capilla Real se fundase el culto público del rosario. ${ }^{12}$

En los cuatro años que permaneció en la silla episcopal de Cádiz Barcia demostró sus innegables dotes de modestia y caridad. Fundó perpetuas misiones en el convento de Santo Domingo, y se convirtió en el gran promotor de los rosarios públicos instituidos por fray Pablo de Cádiz, creándose un total de quince hermandades en memoria de cada uno de los misterios de la Virgen. ${ }^{13}$ Su labor al frente de la diócesis como «Prelado, Pastor y Padre», es alabada en 1694 por fray Miguel del Castillo, prior del convento del Santísimo Rosario y Santo Domingo. ${ }^{14}$ Pero aún no habían cesado para Barcia las responsabilidades. La creación de ejércitos permanentes y la necesidad de regularizar la dirección religiosa militar propició que los vicariatos se establecieran en aquellos lugares donde existían contingentes de fuerzas militares; con relación a la Armada, la alta regiduría de los servicios eclesiásticos castrenses quedó vinculada a Cádiz, de manera que el primer nombramiento de vicario general de la Real Armada del Mar Océano recayó en 1695 en el obispo gaditano.

Poco duraría al frente del cargo. El 14 de septiembre de ese mismo año, una persona difunta a la que había asistido espiritualmente en vida se le aparecía para comunicarle la noticia de su muerte en el plazo de dos meses. En efecto, José Barcia falleció en Cádiz el 30 de noviembre de 1695, a la edad de 52 años. Sus exequias se celebraron el 7 de diciembre en la catedral gaditana, con sermón a cargo de Juan Muñoz de la Cueva, predicador real, teólogo y catedrático de la Universidad de Toledo. ${ }^{15}$ A su muerte le sucederá el jerónimo fray Alonso de Talavera, promovido a la silla episcopal el 18 de julio de 1696.

12. Fray Ambrosio de Valencina: Reseña Histórica de la Provincia Capuchina de Andalucía y Varones Ilustres en ciencia y virtud que han florecido en ella desde su fundación hasta el presente, Sevilla, 1905, 381.

13. Las ordenanzas de las «Compañías Espirituales del Ave María del Santísimo Rosario», con las que fue regulado su rezo público, fueron aprobadas por José Barcia el 19 de junio de 1693. Sobre la devoción al rosario y la celebración de rosarios públicos en Cádiz me remito a FrANCisCo EsPinOSA DE LOS MONTEROS SÁnchez: «Historia de los Rosarios Públicos en Cádiz», Actas del Congreso Internacional del Rosario, Fiestas Mayores, Sevilla, 2004, 419-424.

14. Censura al Despertador Christiano Santoral, de varios sermones de Santos, firmada en el convento gaditano el 9 de mayo de 1694 .

15. Oración fúnebre en las exequias que la Santa Iglesia Cathedral de Cádiz consagró día 7 de diziembre de 1695 a la venerable memoria de su Exemplar Dignissimo Prelado el Illmo. Y Rmo. Sr. D. Ioseph de Barcia y Zambrana. Díxola el M.R.P.Fr. Juan Muñoz de la Cueva, Predicador de Su Majestad... del Orden de la Santissima Trinidad Redempcion de cautivos en su Provincia de Castilla. En Cádiz por Christoval de Requena, año de 1695. 
Diversos testimonios nos acercan al carácter, personalidad y dedicación a su ministerio de José Barcia, como el del canónigo toledano Cristóbal Ruiz. ${ }^{16}$ De su naturaleza dadivosa y caritativa dan fe tanto la fundación de una escuela de niños en la villa solariega familiar de Geve, como los obsequios que hizo al Sacromonte y a San Felipe Neri de Granada. Otras virtudes que lo adornaron fueron su inquietud intelectual y su admiración por el arte tipográfico, notas que hacen de él un ejemplo característico del llamado «intelectual impresor», dado que poseía en Granada una imprenta en la que hizo imprimir gran parte de sus libros, que comprenden los sermones predicados en diferentes lugares a lo largo de su vida, desde que en 1677 viera la luz el primer tomo del Despertador Christiano de Sermones Doctrinales. ${ }^{17}$

Muy pronto se hicieron retratos del ilustre predicador real y obispo gaditano. Su imagen no faltó en la galería de retratos del Colegio de Sacromonte de Granada, ni en la de obispos de Cádiz, esta última conservada actualmente en el pasillo principal del Seminario Conciliar de San Bartolomé. ${ }^{18}$ Pero sin duda, uno de los de mayor categoría es el que realizó el grabador y pintor Juan Bernabé Palomino, con destino a la Cronología de los reyes de España desde el año 417 hasta el de 1759 (Cádiz, 1774) ${ }^{19}$ [Fig. 1]. Se trata de un grabado de formato rectangular en el que se inscribe un óvalo con la verissima efigies del prelado, que muestra un rostro fino, frente despejada y mirada aguda y penetrante, con bigote y perilla alargada. Ataviado con indumentaria episcopal, solideo y cruz pectoral como insignia de su cargo y dignidad, aparece sedente en actitud de escribir, junto a una sencilla mesa de madera que le sirve como escritorio, sosteniendo la pluma en su mano derecha y apoyando la izquierda sobre un libro; diversos objetos quedan encima de la mesa, además del crucifijo que guía su labor doctrinal. Al fondo, un cortinaje parcialmente descorrido deja ver una librería con sus estantes repletos de libros, cuyo lomo permite identificarlos con los distintos tomos del Despertador Christiano. A los pies de la composición, una bella cartela vegetal enmarca una inscripción biográfica con sus principales cargos y dignidades, entre los que no falta el de predicador real de Carlos II; la preside, en el centro, su escudo heráldico, timbrado por el capelo obispal. ${ }^{20}$

16. «Cumple perfectamente con las obligaciones de Doctor Eclesiástico, conformando su regulada vida y ordenadas costumbres, con la doctrina que predica y escribe... sin negarse a la asistencia de Ejercicios espirituales, ni al trabajo del Confesonario, para el consuelo de quien le busca». Aprobación del tomo II del Despertador Christiano Quadragessimal de Sermones Doctrinales...

17. M. José López-Huertas PÉreZ: Bibliografía de impresos granadinos de los siglos XVII y XVIII, t. III, Servicio de Publicaciones de la Universidad de Granada, Granada, 1997, 213-215 y 218.

18. Quiero expresar mi gratitud a D. Luis Palomino, responsable del Archivo Diocesano de Cádiz, por la información facilitada acerca de los retratos de José Barcia en Granada y Cádiz.

19. Elena PÁez Ríos: Repertorio de grabados españoles en la Biblioteca Nacional, t. II, Ministerio de Cultura, Dirección General de Bellas Artes, Archivos y Bibliotecas, Secretaría General, Madrid, 1982, 345.

20. En campo cortado, el primer cuartel trae una torre o castillo apoyado sobre un peñasco y sumado de un brazo sosteniendo una llave, y un segundo elemento de identificación algo más confusa, correspondientes al apellido Barcia; el campo viene rodeado de la inscripción: «Sola virtus hom. hom. par discernit» (Únicamente la virtud distingue a los hombres de los hombres). El segundo cuartel trae castillo 


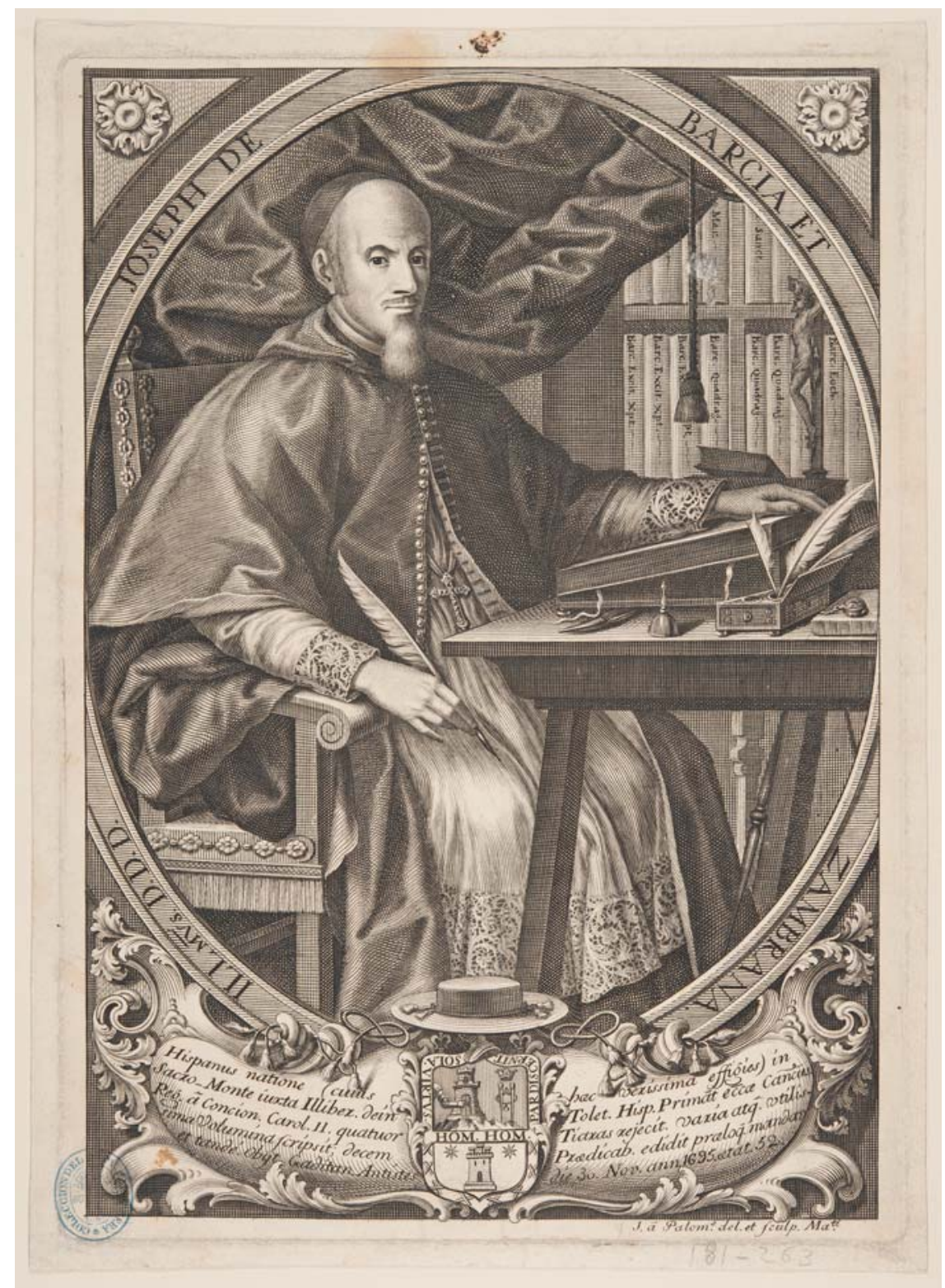

Fig. 1. Juan Bernabé Palomino. Retrato de José Barcia y Zambrana. Aguafuerte y buril, 270 x 193 mm. Biblioteca Nacional de España. Iconografía Hispana, 906

acompañado en su parte superior de dos estrellas, y bordura con ocho aspas, armas de los Zambrana. Para la identificación heráldica hemos consultado Luis VALERo de BERnAbé y MARTín DE Eugenio: Simbología $y$ diseño de la heráldica gentilicia gallega, Ediciones Hidalguía, Madrid, 2003, 329-330; y ENDIKA DE Mogrobejo: Diccionario Hispanoamericano de Heráldica, Onomástica y Genealogía, vol. xiII, Editorial Mogrobejo-Zabala, Bilbao, 1995, 258-268. 
«VOZ DE TRUENO EN LOS PÚLPITOS»: RASGOS DE LA PREDICACIÓN DE JOSÉ BARCIA

Fue José Barcia uno de los más ilustres predicadores de su tiempo, alcanzando el reconocimiento no solo de sus contemporáneos, sino de posteriores estudiosos de la oratoria sagrada española del siglo XVII. ${ }^{21}$ De su sabiduría y claridad expositiva dan fe los sermones impresos que han llegado a nosotros, y que parecen responder de manera fidedigna a los predicados desde el púlpito, a juzgar por el testimonio de un contemporáneo suyo, el canónigo toledano Cristóbal Ruiz, en su aprobación al Despertador Quadragessimal de Sermones Doctrinales:

Habiendo considerado estos sermones, y oído lo que predica, lo que en primer lugar me ha llevado la atención es el ver tan iguales en el Autor la persuasión de sus voces en el Púlpito, y la eficacia con que mueven sus escritos; y he discurrido, que nunca más propiamente que en este ingenio se verifican las calidades que deseaba Justo Lipsio en los escritores, cuando decía: claridad y luz de enseñanza para ilustrar los entendimientos, y calor que inflame las voluntades. ${ }^{22}$

En los prólogos de sus obras, en especial en su «Epístola Exhortatoria a un predicador», que redactó en Madrid el 18 de octubre de 1688 e incorpora al comienzo de varios sermonarios, ${ }^{23}$ expone Barcia su doctrina acerca de los fines, materia y estilo de la predicación, que Juan Muñoz de la Cueva definía de manera muy gráfica en su sermón de exequias: «Con voz de trueno resonaba en los púlpitos el Ilustrísimo Barcia; cuando estallando vivas voces, conmovía y hería con superior eficacia los ánimos de los oyentes». ${ }^{24} \mathrm{El}$ fin de su predicación va dirigido a la búsqueda de la gloria de Dios y a la salvación de las almas; no se trata solo de deleitar y enseñar, sino principalmente de mover y remover las conciencias. El inicio genérico de todos sus sermonarios con el término Despertador es prueba inequívoca de ello, tal y como daba a entender en el prólogo del Despertador Christiano de Sermones Doctrinales. ${ }^{25}$

21. Félix Herrero Salgado: La oratoria sagrada española de los siglos XVI y XVII, Fundación Universitaria Española, Madrid, 1996, 35.

22. Aprobación del Tomo II del Despertador Christiano Quadragessimal de Sermones Doctrinales... El caso de Barcia parece asemejarse al de Fr. Francisco Boíl, predicador real de Felipe IV, en quien según testimonios de sus contemporáneos lo impreso era idéntico a lo predicado. Con todo, debemos ser prudentes al respecto, pues con cierta frecuencia los predicadores se preocupaban de pulir imperfecciones, o de ampliar contenidos que hubiesen dilatado la homilía en exceso. NEGREDO DEL CERRO, Los predicadores de Felipe IV, 269-270.

23. Por deseo del patriarca de las Indias D. Antonio de Benavides y Bazán, el texto de la «Epístola Exhortatoria» se imprimió de manera independiente en la imprenta madrileña de Juan García Infanzón en 1690.

24. Oración fúnebre en las exequias, $1695,5$.

25. «Despertador te ofrezco; y en los materiales, solo se atiende a la voz de la campana, no al bronce frío, o duro hierro, que da los golpes para despertar. Voces hallarás en este Libro de la Divina Escritura, como de campana sonora, en brazos de los Padres de la Iglesia, y Expositores; óyelos si duermes la culpa, para despertar al desengaño, sin reparar en el instrumento de los golpes». Prólogo del Despertador Christiano de Sermones Doctrinales, T. I. Insiste nuevamente en ello en su dedicatoria del Compendio de los cinco tomos del Despertador Christiano al Arzobispo de Lisboa Luis de Sossa (Sousa), al significar que «la aguja de este 
Se ajusta Barcia al ideal clásico de predicación que se mantiene en muchos oradores del siglo XVII, caracterizado por hacer un uso, casi siempre en sentido literal, de la Sagrada Escritura, apoyado principalmente en los Santos Padres, Doctores y Teólogos de la Iglesia, con claridad y corrección en el lenguaje «para que quede el Auditorio instruido», y tendencia a la natural elegancia de estilo. ${ }^{26} \mathrm{El}$ mismo fray Diego de Escalante no duda en agradecer y elogiar este método que hace inteligible la doctrina evangélica «incluso al más ignorante», alejándose de otras modas que habían arraigado con fuerza en la oratoria sagrada de la época. ${ }^{27}$ En efecto, Barcia marca un claro distanciamiento con el denominado «estilo culto», del que huye y al que condena severamente, al punto de lamentar que «la predicación que llaman culta es la mayor persecución que padece la Iglesia de Dios en estos tiempos»; ${ }^{28}$ la razón de esta feroz diatriba radica en que los predicadores «cultos» no predican para gloria de Dios sino para la suya propia, ni buscan la conversión del pueblo, sino su aplauso, actitud por la cual tendrán que rendir cuentas ante la justicia divina.

El esquema de sus sermones obedece casi siempre a un denominador común. A partir de la Salutación o exordio clásico, mediante la cual expone al auditorio la idea central de su discurso relacionada con el Evangelio del día -aplica siempre Barcia el precepto de Cristo: Praedicate evangelium-, desarrolla por extenso su argumentación que articula en varios puntos - «debe el discurso dividirse en tres o cuatro discursos para claridad»-, finalizando con una exhortación directa a cumplir los propósitos que se derivan de su doctrina. Construye en todo momento un eficaz entramado retórico cuyo peso recae en las autoridades sagradas, si bien no renuncia a los autores profanos que le sirven «o para explicación, o para adorno», estableciendo en consecuencia un claro orden de prioridades. Explícito se muestra en este sentido el jesuita José Alcaraz al afirmar que «usa de grande copia de erudición sagrada y profana. Con la primera instruye; con la segunda, adorna. De la primera se vale como de señora; de la segunda se sirve como de esclava». ${ }^{29} \mathrm{El}$ resultado final, confiesa Alcaraz, es un estilo natural, elocuente y hermoso, a través del cual transmite una sólida doctrina. Tal reciedumbre es admitida por el propio Barcia en su prólogo al Despertador de varios Sermones del Santissimo Sacramento del Altar, al significar que «no busqué para estos Sermones sutilezas; sí procuré para ellos solidez, y verdad para la instrucción, remedio y consuelo de las almas».

Relox Despertador pretende señalar a los mortales las horas del desengaño, despertándolos del sueño de la culpa, para que caminen con la luz de la Divina Gracia a la Ciudad eterna de la Gloria». Compendio de los cinco tomos del Despertador Christiano. El Lisboa. En la Officina de Migvel Deslandes, 1684.

26. Herrero SAlgado, La oratoria sagrada española, 259-260.

27. Censura y aprobación del tomo I del Despertador Christiano Quadragessimal de Sermones Doctrinales, realizada por el M. R. P. fray Diego de Scalante, en el convento de Nuestra Señora de la Victoria de Granada, el 4 de julio de 1684.

28. Herrero Salgado, La oratoria sagrada española, 246-247. Acusaciones del mismo tenor se repiten una y otra vez en la mencionada «Epístola Exhortatoria a un predicador».

29. Censura al Despertador Christiano Divino, y Eucharistico, de varios sermones de Dios Trino, y Uno, firmada en el Colegio Imperial de Madrid de la Compañía de Jesús el 28 de junio de 1689. 
Con todo el predicador reconoce servirse a menudo de «symbolos, hierogliphicos y símiles agradables que adornan el oído, para facilitar la inteligencia, y aún el gusto de la doctrina». ${ }^{30}$ Es evidente por tanto que el símil nunca será el verdadero protagonista, mas desde su posición secundaria contribuirá de manera eficaz a docere y delectare, subordinados en todo caso al fin último de la predicación que es movere. En definitiva, una buena comparación recrea el oído y da satisfacción al entendimiento. ${ }^{31}$

El recurso del símil como apoyo de la doctrina sagrada resulta por tanto perfectamente lícito a juicio de Barcia, quien afirma seguir el ejemplo de Cristo:

Uso mucho los símiles, no sólo por seguir a Jesucristo nuestro Maestro, y a los Santos, y antiguos, que tanto los usaron; sino también, porque me ha enseñado la experiencia que es lo que más se imprime a los indoctos; pero he procurado en los más, que sean explicando texto, para que lleve éste el docto y entendido, y el símil lo demás del Auditorio. ${ }^{32}$

Así lo entiende también el canónigo toledano Cristóbal Ruiz cuando asevera que

[...] usa muchas veces el Autor, para mejor explicar las moralidades, de símiles, y lo hace por imitar a Cristo Señor nuestro, que se explicaba con símiles y parábolas. Y también para explicar con más claridad su concepto a la gente ruda, habiendo antes manifestado a los Doctos con el texto; y con este estilo logra la atención de los oyentes, y con suave eficacia los convence. ${ }^{33}$

¿De dónde toma Barcia los símiles? Con suma frecuencia de la Sagrada Escritura, pues considera que contiene símbolos que se adecuan perfectamente a la labor del predicador. Se sirve igualmente de ejemplos de los padres y doctores de la Iglesia, así como de los autores grecolatinos. Y no faltan tampoco imágenes de la literatura emblemática, género que adquirió gran desarrollo durante los siglos XVI y XVII y al que recurren con asiduidad los predicadores a la hora de elaborar sus homilías; la enseñanza didáctico-moral que podía extraerse de las composiciones emblemáticas hace de estas un elemento sumamente apropiado para insertarlas en el excursus religioso, al que proporcionan además un sello de distinción intelectual por su naturaleza culta y erudita. Por tal motivo, si Barcia utiliza símiles populares tomados de la vida cotidiana cuando se dirige a las clases humildes, no duda en recurrir a la emblemática en su predicación a la familia real y a los Consejos, dado que se enfrenta a un público de mayor formación intelectual, capaz de aceptar el juego de ingenio y agudeza propuesto y asimilar la enseñanza que incorpora el jeroglífico o emblema.

30. Prólogo al Despertador Christiano Divino, y Eucharistico, de varios sermones de Dios Trino, y Uno.

31. Herrero Salgado, La oratoria sagrada española, 471-479.

32. Prólogo al Despertador Christiano Quadragessimal de Sermones Doctrinales.

33. Aprobación del tomo II del Despertador Christiano Quadragessimal de Sermones Doctrinales. 
«ECOS DE SU EVANGÉliCA TUBA»: LA PREDICACIÓN DE JOSÉ BARCIA A CARLOS II

Existe unanimidad entre sus contemporáneos al aseverar que Carlos II fue un asiduo practicante de la religión católica, actitud que tenía una de sus principales manifestaciones en su asistencia a los actos litúrgicos celebrados en la Capilla Real y en otros templos de la Villa y Corte. ${ }^{34}$ Será en el solemne marco de estas celebraciones donde se haga presente la oratoria de Barcia a través de sus predicaciones desde el púlpito. ${ }^{35}$ Sin duda, la presencia en la Corte de Portocarrero, figura destacada en el gobierno carolino en la última década del siglo xViı y valedor de Barcia en Toledo, le abrió las puertas del Alcázar y facilitó su aproximación al monarca y a los órganos de gobierno de la corona española. Así lo constataba Juan Muñoz de la Cueva en su sermón de exequias:

Fue el señor D. José Barcia aquél a quien buscó en su retiro la vigilante solicitud del Eminentísimo Sr. Cardenal Portocarrero, para que colocado en el Coro de la Primada Iglesia en Toledo, y en la Corte, en los oídos de nuestro Piísimo Monarca resonasen los ecos de su Evangélica Tuba. ${ }^{36}$

En total, son quince los sermones recogidos en los diferentes tomos del Despertador Christiano que predicó, bien al rey, bien a la familia real, en un período comprendido entre 1687 y 1691 (incluimos en esta secuencia cronológica los pronunciados con antelación a su nombramiento oficial en 1689). Algunos de ellos adquieren especial significación, como el dirigido a Carlos II en la iglesia de San Jerónimo de Madrid el 23 de febrero de 1689, recién estrenado en el cargo y tan solo once días después del fallecimiento de María Luisa de Orleans, o el de acción de gracias por los nuevos desposorios con Mariana de Neoburgo celebrado en la Capilla Real el 28 de mayo de 1690, pasados seis días de su entrada en Madrid. ${ }^{37}$ Apenas tres meses más tarde, el 2 de septiembre del mismo año, la reina lloraba la muerte de su padre, Felipe

34. JuAn A. SÁnChez Belén: «La muerte os sienta tan bien, Majestad. La imagen de Carlos II en los sermones fúnebres», Carlos II. El rey y su entorno cortesano, Centro de Estudios Europa Hispánica, Madrid, $2009,332$.

35. Sobre la importancia que adquiere la oratoria sagrada del siglo XviI dirigida al monarca desde el púlpito, convertido en lugar privilegiado de difusión ideológica, contamos con las valiosas aportaciones de Fernando Negredo del Cerro: «La palabra de Dios al servicio del Rey. La legitimación de la Casa de Austria en los sermones del siglo XVII», Criticón, n. ${ }^{\circ}$ 84-85, 2002, 295-311; «La Capilla de Palacio a principios del siglo Xvir. Otras formas de poder en el Alcázar madrileño», Studia Historica, Historia Moderna, n. ${ }^{\circ} 28$, 2006, 63-86; y las ya citadas de ÁlvArez-Ossorio Alvariño, «La sacralización de la dinastía en el púlpito de la Capilla Real...», 313-332; y «Facciones cortesanas y arte del buen gobierno...», 99-123.

36. Oración fúnebre en las exequias, 1695, 2.

37. Tras la ratificación en Valladolid de los esponsales por poderes que habían tenido lugar en Neoburgo, la reina hizo su entrada en Madrid el 22 de mayo de 1690, con decoración efímera ideada por Antonio Palomino y Francisco Ignacio Ruiz de la Iglesia. Teresa Zapata Fernández de la Hoz: «La entrada de María Ana de Neoburgo (1690). Una decoración efímera de Antonio Palomino y Francisco Ignacio Ruiz de la Iglesia», Anuario del Departamento de Historia y Teoría del Arte, n. ${ }^{\circ}$ 9-10, 1997-1998, 257-276. 
Guillermo de Wittelsbach, duque de Neoburgo y elector palatino del Rhin; al conocer la noticia, Carlos II decretó duelo oficial en la Corte, y el 9 de noviembre se celebraba en la Capilla Real una ceremonia de honras fúnebres con predicación a cargo de Barcia. ${ }^{38}$

La mayoría de estos sermones -concretamente diez- fueron predicados por Barcia en la Capilla Real del Alcázar, que en la monarquía austriaca desempeñó un destacado papel político-religioso. ${ }^{39}$ En efecto, fue la Capilla Real uno de los espacios primordiales de la vida áulica durante el siglo XVII, escenario de exaltación de la familia real donde en los «días de cortina» en los que el rey asistía públicamente, se desplegaba todo un ceremonial que acrecentaba, en un lenguaje simbólico-ritual, las singulares prerrogativas de las que como Monarchia Catholica recaían en la Casa de Austria. ${ }^{40}$ Desde el púlpito, ubicado en el lado de la Epístola, en un lugar privilegiado casi frente por frente con el sitial del rey, «los predicadores reales expusieron en los sermones unos discursos muy elaborados sobre la santidad del trono y de la estirpe coronada», significa Álvarez-Ossorio ${ }^{41}$ [Fig. 2]. En el calendario de festividades que se celebraban en la Capilla Real se distinguían ante todo los días que había misa cantada y sermón, en los que los cortesanos seguían con expectación la alocución del predicador y la elocuencia demostrada en sus argumentaciones. ${ }^{42}$

Fuera de la Capilla Real, cuatro sermones tuvieron como escenario el monasterio de San Jerónimo, y uno - predicado a Mariana de Austria en 1687la capilla de las Descalzas Reales. En algunos casos podemos precisar el día en que Barcia se dirigió a la familia real, caso de los predicados a Carlos II el 29 de junio y el 1 de noviembre de 1689 con motivo de las festividades de san Pedro y de Todos los Santos; e incluso concretar el momento y la hora del día, como ocurre con los sermones dirigidos al monarca las tardes del Lunes Santo de 1688 y del Viernes Santo de 1689, este último comenzado a las tres en punto.

Pese a su teórica invulnerabilidad al hablar desde un lugar sacro e inviolable como es el púlpito, Barcia es consciente de la responsabilidad que implica dirigirse a los miembros de la monarquía, y a cuantos acompañan al rey en las grandes funciones religiosas. Así lo pone de manifiesto al comienzo de

\footnotetext{
38. El sermón de honras fúnebres en memoria del padre de Mariana de Neoburgo es citado por Álvarez-Ossorio Alvariño, «La sacralización de la dinastía en el púlpito de la Capilla Real...», 315.

39. Veronique Gérard: «Los sitios de devoción en el Alcázar de Madrid: Capilla y Oratorios», Archivo Español de Arte, n. ${ }^{\circ}$ 221-224, 1983, 275-284. CARMelo Lisón Tolosana: La imagen del rey. Monarquía, realeza y poder ritual en la Casa de los Austrias, Espasa Calpe, Madrid, 1992.

40. Véase a este respecto el sugerente estudio de Jorge FERnÁndEZ-SAnTos OrTiz-Iribas: «Ostensio regis. La Real Cortina como espacio y manifestación del poder soberano de los Austrias españoles», Potestas. Revista del Grupo Europeo de Investigación Histórica, n. . 4, 2011, 167-209.

41. Antonio Álvarez-Ossorio Alvariño: «Ceremonial de la Majestad y protesta aristocrática. La Capilla Real en la corte de Carlos II», La Capilla Real de los Austrias. Música y ritual de corte en la Europa moderna (eds. Juan José Carreras Ares y Bernardo José García García), Fundación Carlos de Amberes, Madrid, 2001, 345.

42. Álvarez-Ossorio Alvariño, «Facciones cortesanas y arte del buen gobierno», 101.
} 


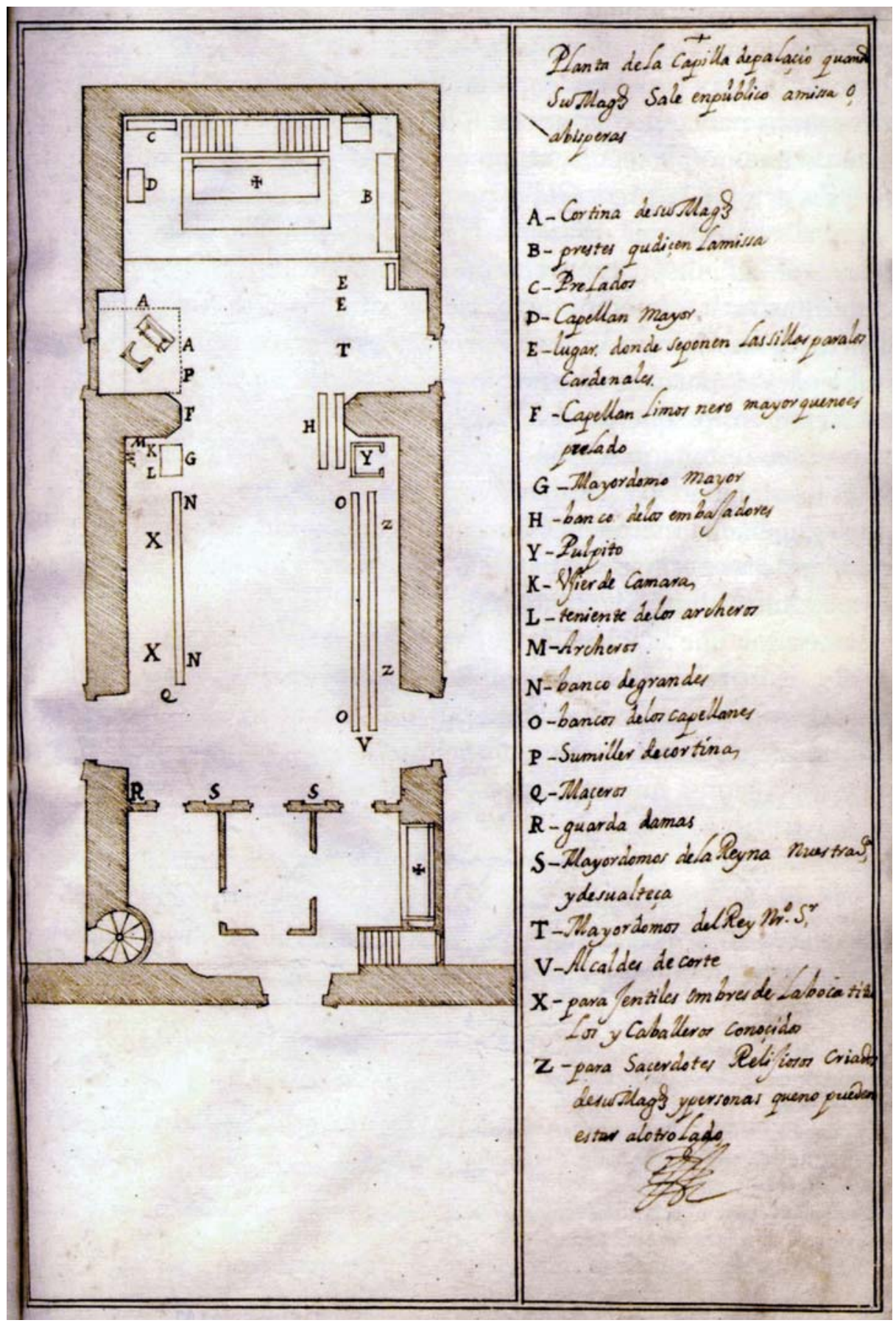

Fig. 2. JuAn Gómez de Mora. «Planta de la Capilla de palaçio cuando Su Magd Sale en publico a missa o a bisperas» (c. 1650). Tinta parda sobre papel verjurado, 195 x $286 \mathrm{~mm}$. (Archivo General de Palacio, Sección Histórica, caja 51, f. 186 r. Patrimonio Nacional, Madrid) 
algunos sermones predicados a Carlos II en la Capilla Real, como el del Lunes Santo de 1688, en el que el paralelismo con la figura del profeta Daniel ante el rey Nabucodonosor le permite enumerar las dificultades que entraña su misión, que debe guiarse en todo momento por la verdad, aunque esta resulte incómoda a una parte de su auditorio. ${ }^{43}$ Una reflexión similar lleva a cabo con motivo del sermón pronunciado ante el monarca en febrero de 1689, que iniciaba de esta manera:

Grande es siempre la obligación del Predicador Evangélico, Ministro de la salud de las almas; pero en este puesto, crece hasta ser inmensa esta obligación. ¡Predicar a Reyes! Dios quitó la elocuencia a Moisés al enviarlo a Egipto a predicar, para que viendo que le enviaba a que fuese predicador del Rey, advirtiese que para predicar a los Reyes, más que la elocuencia, es menester espíritu con que proponer la verdad. ¡Grande, aunque temerosa advertencia, para quien sube a este puesto!. ${ }^{44}$

Indudablemente, en la trascendencia que adquiere la verdad como soporte del sermón regio, se encuentra el hecho de que la predicación de Barcia, sin dejar de tener un marcado carácter doctrinal -la alabanza a Dios y la salvación de las almas constituyen fines irrenunciables-, supone también un intento por trazar la personalidad del monarca y orientarle desde la doctrina cristiana en la toma de decisiones, que debe inscribirse en un contexto más amplio del debate político en torno al rey y a la monarquía de España que ya fuera advertido por Adolfo Carrasco. ${ }^{45}$ El sermón se convierte así en una valiosa pieza de teología política orientada a ensalzar la Pietas Austriaca y los principios legitimadores de la dinastía, en la que tienen cabida igualmente la censura a la actuación de los gobernantes, la crítica a los abusos políticos, y

43. Es probable, por la manera en que da principio a su homilía, que el sermón predicado el Lunes Santo de 1688 fuese el primero dirigido por José Barcia a Carlos II, previo a su nombramiento como predicador real. En él plantea además una verdadera declaración de intenciones acerca del compromiso de quien se dirige al monarca desde el púlpito, que resulta sumamente explícita de las dificultades a las que se enfrenta: «No había conocido bien mi cortedad, hasta esta experiencia, en que estuvo la grande dificultad con que Daniel se vio embarazado para predicar a un Rey... Hallóse Daniel con un mandato del Rey para predicar; miróse entre la lealtad, y el respeto. De una parte, el respeto con el temor le encogía; de otra, la lealtad con el amor le alentaba. Si hablo (dice) contra el desorden del gobierno de la Monarquía, ayudaré a desacreditar el gobierno, que es un inconveniente gravísimo. Si toco en individualidades del Rey, me podrá decir, y con razón, que se lo dixera en audiencia particular. Si trato de los defectos de los Ministros, será fomentar la murmuración del pueblo, que siempre se quexa de los que mira su envidia superiores. Si digo la verdad clara con desnudez, parecerá a los discretos de Palacio sobrada libertad. Si la callo, faltaré a la obediencia de mi Rey... Esta era la lucha de los pensamientos de Daniel; pero en fin determinó dar principio a su Sermón, alentado con la presencia del Príncipe, que deseaba oír no lisonjas, sino desengaños de la verdad. Así Daniel; y yo también así: que pues describió en sus congojas mis congojas, en su Sermón tengo de fundar mi Sermón, que será del juicio que hace Dios de un Rey». Despertador Christiano Quadragessimal de Sermones Doctrinales, t. III (ed. Madrid, 1697), 150-151.

44. Despertador Christiano Quadragessimal de Sermones Doctrinales, t. I (ed. Cádiz, 1697), 35.

45. Adolfo Carrasco Martínez: «El príncipe deliberante abstracto. Debate político en torno al rey y la Monarquía de España (1680-1700)», Carlos II. El rey y su entorno cortesano, 81-107. 
la propuesta de reformas en la administración de los reinos. ${ }^{46}$ Desde el púlpito, pero también desde la cercanía a la familia real, el predicador de Su Majestad trata de proporcionar unas pautas para que este se conduzca, al igual que lo hicieron sus antepasados, como un auténtico príncipe político-cristiano. No es de extrañar en consecuencia que buena parte de las imágenes emblemáticas propuestas por Barcia al monarca provengan de la Idea de un príncipe político cristiano del diplomático murciano Diego Saavedra Fajardo, uno de los autores más representativos del reinado de Felipe IV. ${ }^{47}$

\section{LA CONCEPCIÓN PROVIDENCIAL DE LA MONARQUíA HISPANICA}

Para el conjunto de la Cristiandad, Carlos II era el rey cristiano, dignidad reconocida como tal en toda Europa, pues no había una monarquía que hubiera demostrado tanto celo en la defensa decidida de la fe, frente a las múltiples y diversas manifestaciones heréticas. ${ }^{48}$ Aunque no es momento este de profundizar en su riqueza iconográfica, la estampa del grabador flamenco Martin Bouché (1640-1693) que representa a Carlos II como rey católico de las Españas (Carolus II Hispaniar. Indiar. et Rex Catholic), soberano de tierra y mar, acompañado de diversas alegorías y símbolos del poder, es fiel reflejo de esta concepción universal ${ }^{49}[$ Fig. 3].

46. Como señala Álvarez-Ossorio, «en determinadas coyunturas, los predicadores que ocupaban el púlpito de la Capilla no se limitaban a exponer recomendaciones genéricas de celo religioso, sino que señalaban aspectos concretos de la vida áulica, instando al remedio urgente». Álvarez-Ossorio AlvARIÑo, «Facciones cortesanas y arte del buen gobierno...», 111. A las peculiares circunstancias que conformaban el ejercicio del púlpito en la Capilla Real aluden también FrANCIS CERDÁN: «El púlpito de la Capilla Real en la época de los Austrias. Receptáculo y eco sonoro de la cultura del Barroco», La Capilla Real de los Austrias. Música y ritual de corte en la Europa moderna, 305-321; y FERNANDo NEGREdo DEL CERRO: «Las atalayas del mundo. Los púlpitos y la explicación eclesiástica de la decadencia de la monarquía», La declinación de la monarquía hispánica en el siglo XVII (coord. Francisco José Aranda Pérez), Ediciones de la Universidad de Castilla-La Mancha, Cuenca, 2004, 863-878.

47. Debemos significar a este respecto que no es nuestro propósito hacer un recorrido completo por la fortuna emblemática de las imágenes propuestas por Barcia, sino limitarnos únicamente a los autores que cita en los marginalia de los sermones o, en todo caso, a la fuente original a la que se remiten aquellos en su obra.

48. Jaime Contreras: Carlos II el Hechizado. Poder y melancolía en la corte del último Austria, Ediciones Temas de Hoy, Madrid, 2003, 210.

49. El monarca aparece de busto, mirando de frente, vestido de negro y con el Toisón de Oro; su figura se inscribe en un óvalo formado por ramos de encina y laurel entre las columnas de Hércules. A los pies se acumulan diversos objetos simbólicos. El conjunto queda enmarcado en una portada arquitectónica con figuras alegóricas (Religión o Piedad, Fe, Dominio de la Monarquía), en tanto que en la cartela del zócalo se narra el episodio en el que Carlos II, tras ofrecer su carroza al sacerdote que portaba el santo Viático, asiste a la ceremonia de la extremaunción y comunión de un hortelano moribundo. ElenA PÁEZ Ríos: Iconografía hispana. Catálogo de los retratos de personajes españoles de la Biblioteca Nacional, vol. I, Biblioteca Nacional, Madrid, 1966, 498. Nacido en Amberes en 1640, Martin Bouché fue un grabador que se distinguió particularmente por sus retratos, sobre todo de diferentes miembros de la Compañía de Jesús. Joseph Strutt: A Biographical Dictionary of Engravers, vol. I, Printed by J. Davis, Londres, 1785, 132. 


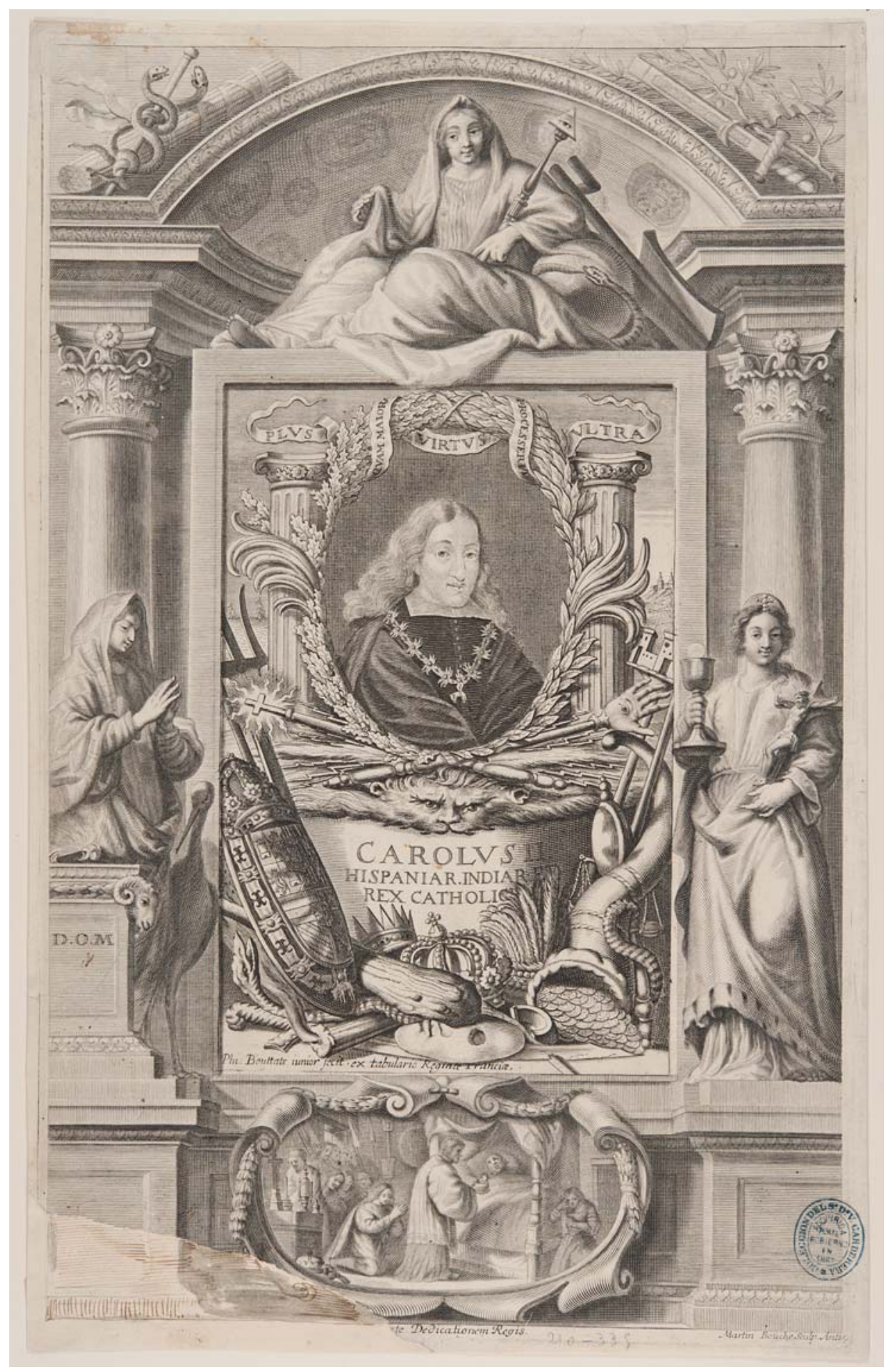

Fig. 3. Martín Bouché. Retrato de Carlos II. 340 x 212 mm. (Biblioteca Nacional de España. Iconografía Hispana, 1710-1717) 
La visión sacralizada de la monarquía hispana -o era católica, o no lo erase mantiene por tanto en la persona del último de los Austrias, de manera que la teoría del providencialismo divino no resulta anacrónica ni mucho menos a finales del siglo XVII. ${ }^{50}$ Semejante concepción del poder real parte del hecho de considerar que la monarquía española goza de la especial protección divina, para colocar al soberano en una posición intermedia entre Dios y los súbditos: «El Rey es en su monarquía un vice-Dios», llega a afirmar Barcia en el sermón dirigido a Su Majestad el Lunes Santo de $1688 .{ }^{51}$

La concepción providencialista de la monarquía es puesta de manifiesto por Barcia en multitud de sermones, no solo en los predicados a la familia real, sino también a los Consejos. Quizás el más significativo sea el dirigido a Carlos II en 1691, a propósito de la parábola evangélica de la viña (Mt 21, 33-45) que acababa de proclamar. ${ }^{52}$ En su argumentación, el orador afirma que los reinos y principados dependen de la providencia de Dios, quien como monarca supremo puede otorgarlos y quitarlos con sabia justificación..$^{53}$ Para ejemplificar tal aseveración, se sirve de la imagen del cetro recogida por Picinelli en su Mundus Symbolicus, en referencia a que todo poder viene de Dios (Per me regnant), tal y como lo confiesan los reyes de la monarquía hispana al encabezar sus reales despachos con la expresión «Por la Gracia de Dios, Rey de...». ${ }^{54}$ Mas en realidad, el abad milanés toma el contenido de la empresa 18 de Saavedra Fajardo, que con el mote $A$ Deo (De Dios) muestra en su pictura una mano que sostiene simultáneamente un timón y un cetro rematado en una luna menguante orientada hacia unos rayos de sol, todo ello delante de un globo terráqueo [Fig. 4]. Señala el diplomático murciano que «siendo Dios por quien reinan los reyes, de quien dependen su grandeza y sus

50. Acerca del providencialismo divino como seña irrenunciable de la Casa de Austria, y de su manifestación a través de la literatura emblemática -en concreto de las Empresas Políticas de Saavedra Fajardo-, reflexionamos en José JAvier Azanza López: «An Emblematic Reading of a Regal Epistolary Exchange: Philip IV's Letters to Sister María de Ágreda, in the Light of Saavedra Fajardo», In Nocte Consilium. Studies in Emblematics in Honor of Pedro F. Campa (eds. John T. Cull and Peter M. Daly), BadenBaden, Verlag Valentin Koerner, 2011, 43-86.

51. Despertador Christiano Quadragessimal de Sermones Doctrinales, t. III (ed. Madrid, 1697), 157. Esta concepción «cuasi divina» de la monarquía ya había sido puesta de manifiesto décadas atrás en un sermón predicado en Sevilla por el jesuita Rodrigo Manrique al afirmar que «los Príncipes y Reyes y monarcas son unos vicedioses en la tierra por ser puestos por Su Majestad para gobernarla». MiguEL ÁNGEL NúÑEZ Beltrán: La oratoria sagrada de la época del Barroco. Doctrina, cultura y actitud ante la vida desde los sermones sevillanos del siglo XVII, Universidad de Sevilla y Fundación Focus-Abengoa, Sevilla, 2000, 366.

52. Despertador Christiano Quadragessimal de Sermones Doctrinales, t. II (ed. Madrid, 1697), 13-23.

53. El sentido de su disertación puede ponerse en contacto con el expresado por el canónigo, historiador y jurisconsulto Diego Felipe de Albornoz en su Cartilla política y cristiana (1666), donde afirmaba que «no mantiene las coronas la razón de Estado sino Dios, que como dueño universal de los reinos los muda, altera o conserva, y así es necesario reverenciarle como a supremo Señor del dominio directo». JuAN CARLOS SaAvedra Zapater y Juan A. Sánchez Belén: La cartilla politica y cristiana de Diego Felipe de Albornoz, Universidad Nacional de Educación a Distancia, Madrid, 2007, 91. También son de gran interés los ejemplos que seis años más tarde proporciona el doctor salmantino y preceptor de Carlos II Francisco Ramos del Manzano en su obra Reynados de menor edad y de grandes reyes (1672) para justificar la conservación de sus reinos por parte de reyes y emperadores a lo largo de la historia. Francisco Ramos del Manzano: Reynados de menor edad y de grandes reyes. Apuntamientos de Historia, Francisco Sanz, Madrid, $1672,71$.

54. Filippo Picinelli: Mundus Symbolicus (ed. 1687), Libro XXV, cap. XXIV, n. ${ }^{\circ} 83$. 
aciertos, nunca podrán errar si tuviesen los ojos en Él»..$^{55}$ En consecuencia, el príncipe debe conservar siempre firme su cetro y mirar (como la Luna al Sol) a la virtud suprema que es Dios, de quien dependen la grandeza y los aciertos en el gobierno terrenal.

Todo poder en la tierra procede de Dios, que es quien concede el cetro y la corona, y que dio a la Casa de Austria la viña del reino español para que el monarca la cultive con el ejemplo y las leyes hasta obtener el fruto de la salvación eterna de sus vasallos. Es, por tanto, el oficio de reinar oficio de labrador, y de

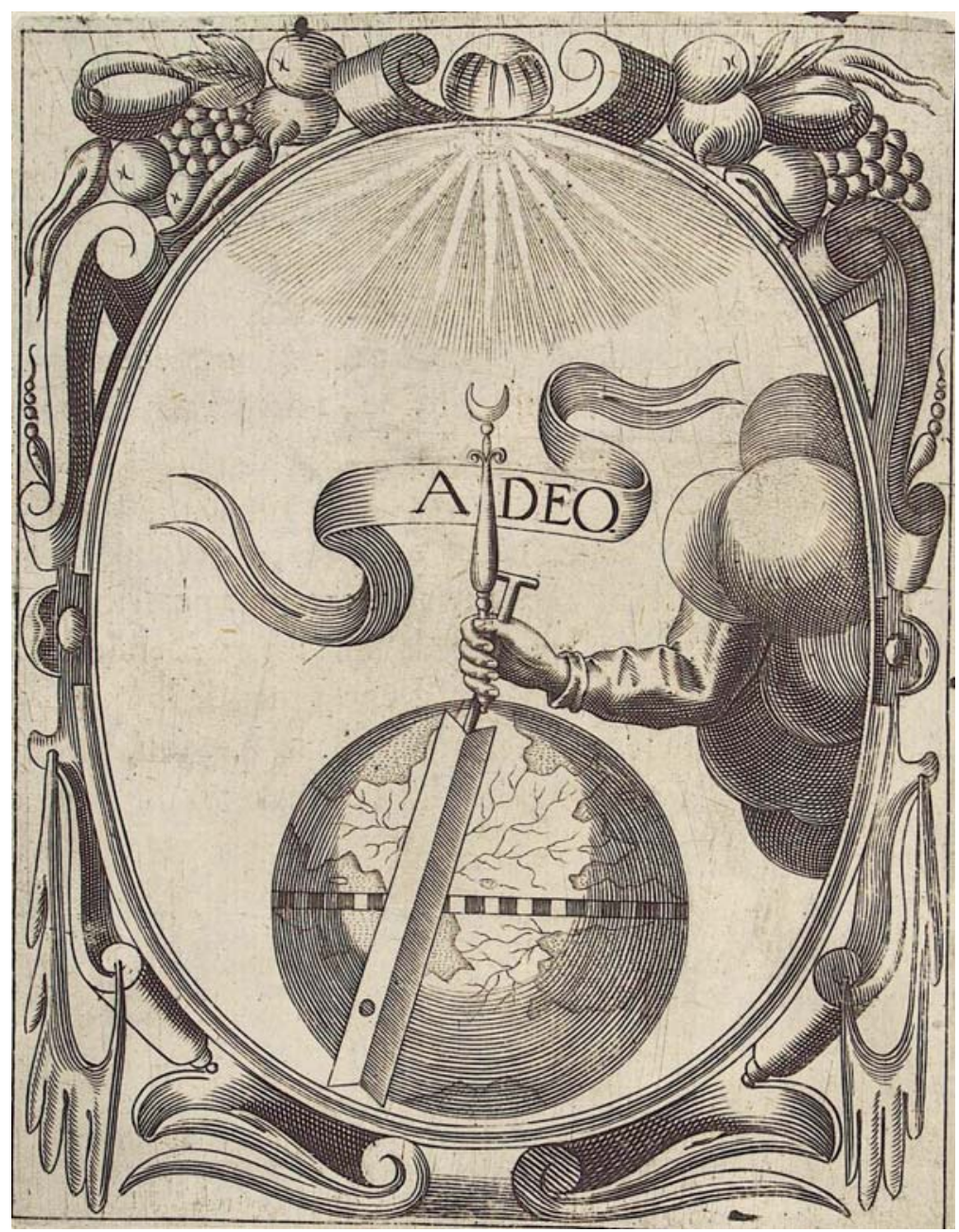

Fig. 4. Diego SaAvedra Fajardo. Idea de un Príncipe Político Cristiano. Empresa 18. A Deo

55. Diego Saavedra Fajardo: Empresas políticas (ed. Sagrario López Poza), Cátedra, Madrid, 1999, 369-377. Jesús M. a González de ZÁrate: «Análisis de las Empresas Políticas de Diego Saavedra Fajardo», Traza y Baza. Cuadernos Hispanos de Simbología, n. ${ }^{\circ} 10,1985,12-13$. 
ahí que en la antigüedad se pintase un arado con el que se labra la tierra para significar el cetro con que se gobierna una monarquía, remitiéndose Barcia en su comparación a un jeroglífico de los Hieroglyphica de Pierio Valeriano que muestra al cetro y al arado unidos y preparados para cultivar un terreno ${ }^{56}$ [Fig. 5]. Mas el Señor puede quitar el reino al príncipe desobediente e ingrato por no ser merecedor de él, y de ahí el aviso final a Carlos II: la providencia le ha concedido el privilegio y la responsabilidad de reinar, y es su obligación cultivar las vidas de sus vasallos para lograr los frutos de virtud con que pagar al Dueño de la viña; de lo contrario, es de temer que la poderosa mano de la Divina Justicia escriba la sentencia de su destrucción.

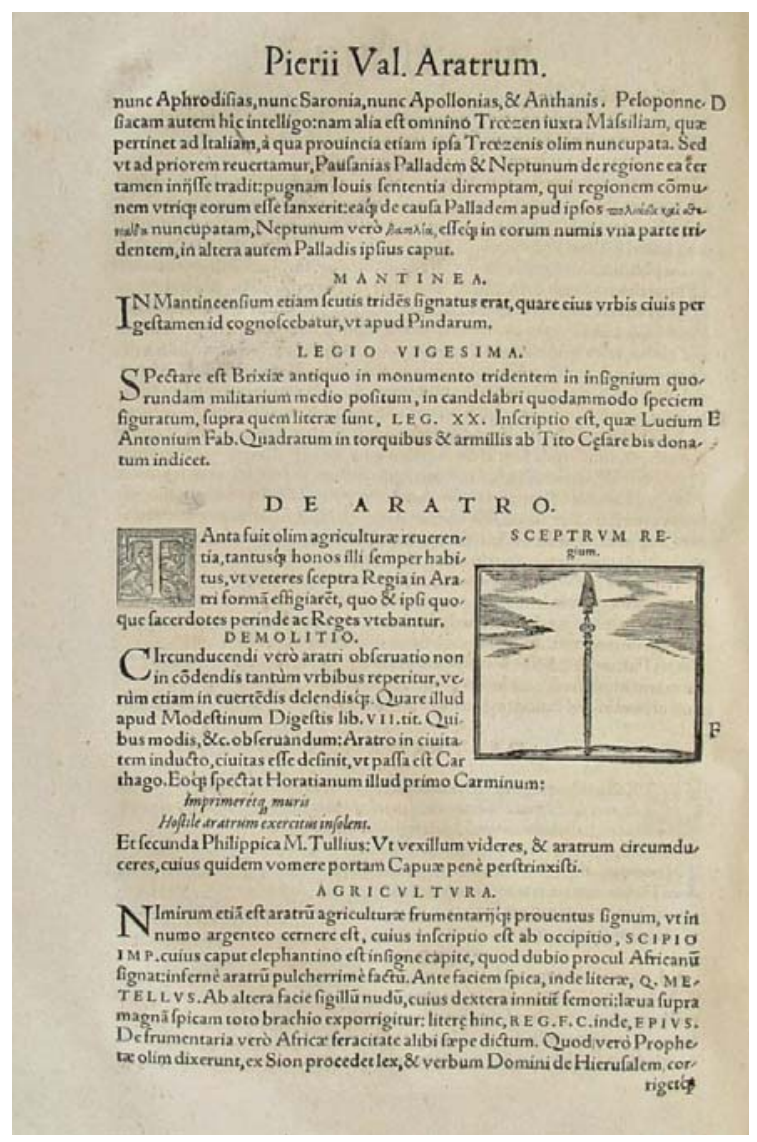

Fig. 5. Piero Valeriano. Hieroglyphica. Libro XLVIII

56. Pierio Valeriano: Hieroglyphica, seu de Sacris Aegyptiorum aliarumque gentium literis commentarii. Venetiis, Apud Io. Antonium \& Iacobum de Franciscis, 1604, Libro XLVIII. 
LA CONDUCTA VIRTUOSA COMO GARANTE DE LA MONARQUía: LAS TRES LETRAS DE LA PALABRA «REY»

El monarca debe estar adornado de virtudes que aseguren la eficacia política: «Con más virtudes que consejeros tendrán acierto los despachos. El príncipe con consejeros es hombre y pueden unos y otros errar; con virtudes es ángel, y no será fácil que yerre», significaba al respecto el dominico Ferrer de Valdecebro en El cetro con ojos, manual para la educación del príncipe editado en $1678 .^{57}$ Tres años antes, la presencia alegórica de un conjunto de virtudes en la portada de la Política Real y Sagrada, de Juan Vela, condensaba gráfica y conceptualmente una conducta basada en las virtudes cristianas y políticas, convirtiéndose en un magnífico testimonio en torno al ideal monárquico. ${ }^{58}$ Ya en las postrimerías del reinado carolino, un opúsculo de Gabriel Álvarez Pellicer proponía unas Breves reglas para gobernar en las que asomaban una vez más las virtudes que debía poseer el monarca para ejercer con éxito el poder, erigiéndose en esta ocasión Justicia y Verdad en las dos grandes columnas sobre las que sustentar tan difícil misión. ${ }^{59}$

En consonancia con los anteriores, también Barcia insiste en la conducta virtuosa del monarca como garante del éxito de su reinado. A su juicio, las principales virtudes que debe observar Carlos II están condensadas en su propio título: «De las tres letras que componen el nombre de Rey, la $\mathrm{R}$ advierte el celo de la Religión al príncipe; la E avisa el Ejemplo de honestidad; y la última es la Y, en que se lee su Justicia, de la que es el Rey administrador supremo». Es evidente por tanto que, para el predicador real, Religión, Ejemplo y Justicia son las bases sobre las que el rey debe asentar el gobierno de sus estados.

La religiosidad que debe guardar Carlos II procede de la propia concepción providencialista de la monarquía española, por la cual se considera que goza de la protección divina. En un sermón predicado al monarca en 1690 tras la lectura de la multiplicación de los panes y los peces (Jn 6, 1-15), el orador recuerda que se ha establecido un pacto entre Dios y el reino, por el cual el Señor ofrece su especial protección y el reino asegura la defensa de su fe; en consecuencia, el monarca debe confesar en todo momento su religiosidad y depositar su confianza en Dios y no en los bienes terrenales. ${ }^{60} \mathrm{Y}$ pone como ejemplo un emblema de Alciato que con el lema Potentia amoris (El poder del amor) muestra a Cupido alado con un ramo de flores -o espigas, según Barcia, para cuadrar mejor la comparación- en una mano y un pez en la otra, para significar que tanto en la tierra como en el mar todo está sujeto al imperio del amor ${ }^{61}$ [Fig. 6]. Pues si este fingido dios se presenta como rey, así también el verdadero Dios de Amor que es Cristo se manifiesta en el pasaje evangélico

57. Andrés Ferrer de Valdecebro: El príncipe con ojos, Francisco Sanz, Madrid, 1678, 14.

58. CARRASCO MARTínez, «El príncipe deliberante abstracto», 83.

59. Gabriel Álvarez Pellicer: Breves Reglas para gobernar, Madrid: s.a., s.p.

60. Despertador Christiano Quadragessimal de Sermones Doctrinales, t. II, 236-246.

61. Andrea Alciato: Emblemas (ed. Santiago Sebastián), Akal, Madrid, 1993, 141-142. 


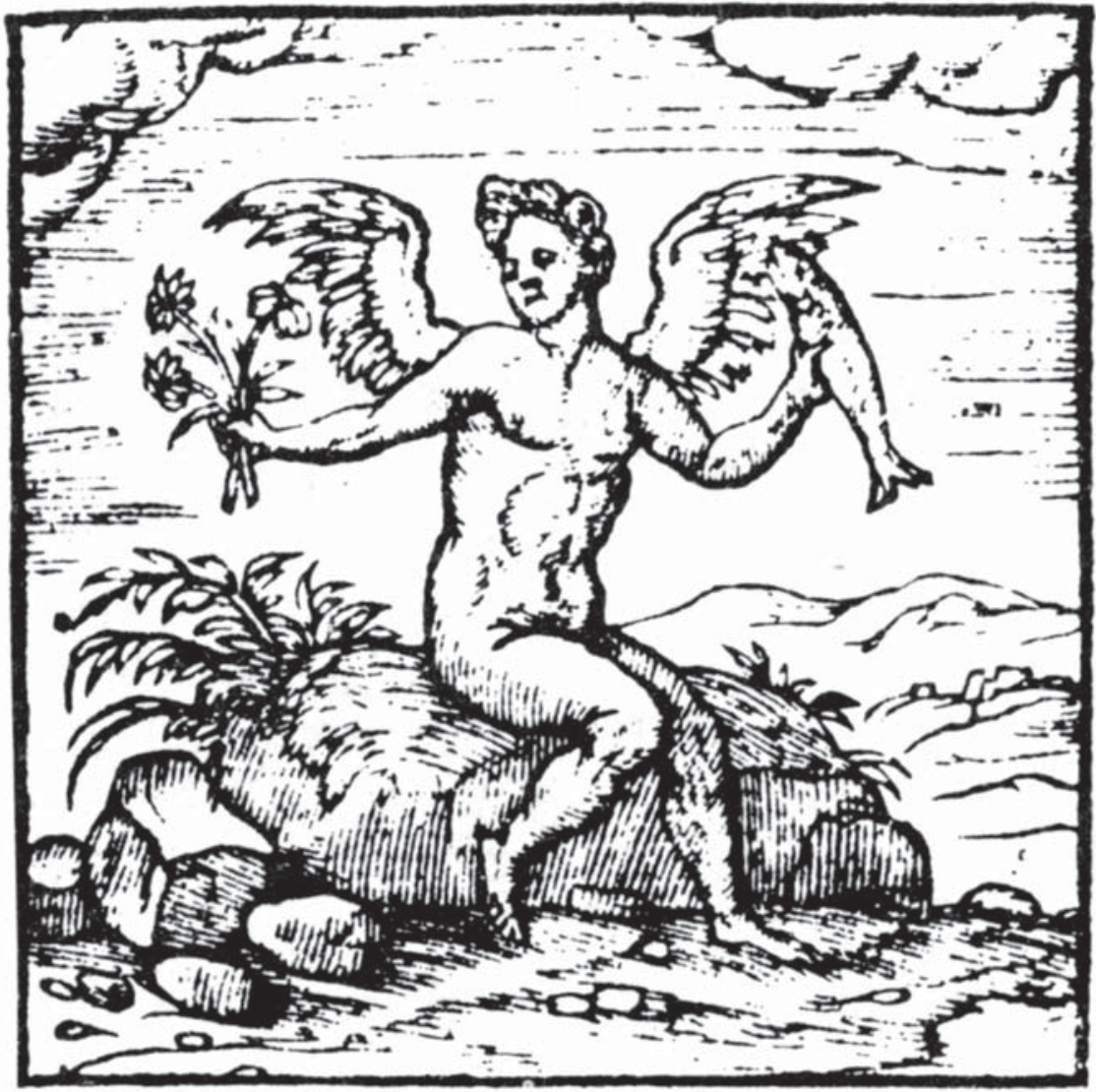

Fig. 6. Alciato. Emblematum libellus. Potentia amoris

como Señor de tierra y mar, con panes y peces con los que obró el milagro. Así pues, el monarca no debe dejarse engañar por los falsos dioses que con sus alas podrían abandonarlo en cualquier instante, sino acogerse a la roca de Cristo para mantener constante la religiosidad del reino.

Roca es Cristo sobre la que sustentarse, y roca es también san Pedro, sobre la que el Señor fundó su Iglesia. Sirviéndose de un conjunto de imágenes emblemáticas, el sermón predicado a Carlos II el 29 de junio de 1689 permite a Barcia establecer una triple relación entre la monarquía, el lugar de la predicación -la Capilla Real- y el pasaje evangélico que acababa de proclamar (Mt 16). ${ }^{62}$ Comienza significando que el águila, reina de las aves, es símbolo propio de la majestad real. Son varios los motivos que justifican esta comparación, y entre ellos se encuentran las cualidades que atribuye Saavedra 
Fajardo al águila en la empresa 22 de sus Empresas Políticas, en la que con el mote Praesidia maiestatis (Defensas de la majestad), muestra bajo una corona la simbiosis de dos medias aves de alas explayadas fundidas por su eje corporal: un águila con los rayos jupiterinos en las garras, y un avestruz que sujeta una herradura con el pico, en alusión a que la justicia ha de ser también clemente [Fig. 7]. Sigue Barcia al pie de la letra a Saavedra al afirmar que en el águila se encuentran las tres cualidades principales que debe poseer todo monarca en el ejercicio de la justicia: la agudeza de su vista para vigilar su reino, la ligereza de sus alas para ejecutar con rapidez sus resoluciones, y la fortaleza de sus garras para mantener su entereza y no desfallecer. ${ }^{63}$

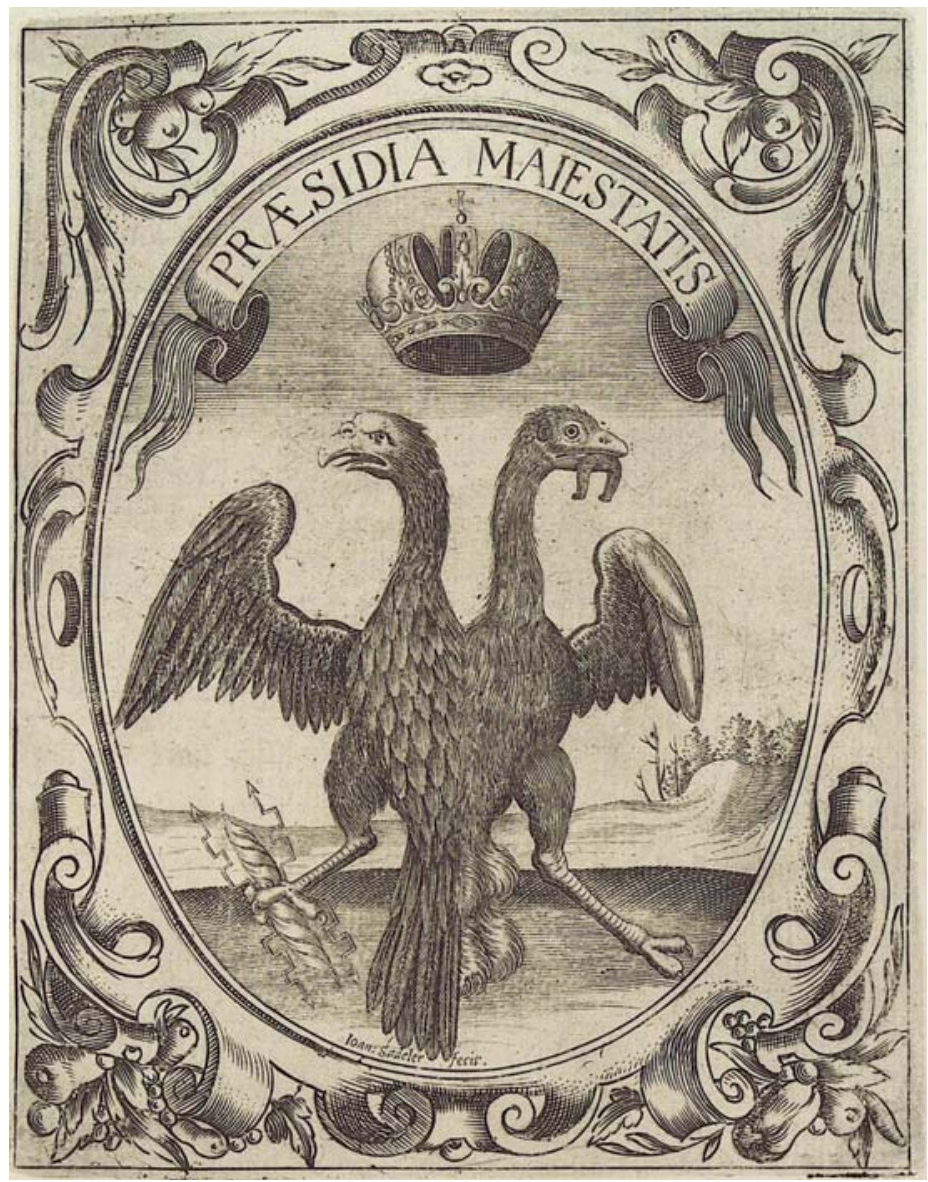

Fig. 7. Diego Sanedra Fajardo. Idea de un Príncipe Político Cristiano. Empresa 22. Praesidia maiestatis

63. SaAVedra Fajardo, Empresas politicas, 329-341. GonzÁlez de ZÁrate, «Análisis de las Empresas Políticas...», 33-34. José Julio García Arranz: Symbola et emblemata avium. Las aves en los libros de emblemas y empresas de los siglos XVI y XVII, SIELAE y Sociedad de Cultura Valle Inclán, A Coruña, 2010, 194. 
Mas no son estas las únicas virtudes que encuentra el predicador en el águila, pues según una antigua tradición a la que aludía Plinio y de la que se harán eco autores como san Isidoro de Sevilla, Pedro Bercorio o el obispo de Tortona Paolo Aresi -todos ellos citados por Barcia-, el águila traía para el edificio de su nido una piedra llamada aetites que resultaba ser útil no solo para reforzarlo y darle solidez, sino que lo protegía de las serpientes venenosas e incluso aseguraba la procreación de las aves. La imagen del águila transportando una piedra a su nido es recogida por diversos autores, ${ }^{64}$ entre ellos Horapolo, quien señala que los antiguos egipcios la consideraban expresión del hombre que busca seguridad en su ciudad protegiéndose de los males ${ }^{65}$ [Fig. 8]. Con Horapolo coincide Pierio Valeriano en sus Hieroglyphica -fuente que cita Barcia- al relatar el suceso del águila que porta una piedra para su nido como imagen del hombre que se ha establecido con seguridad en una ciudad. Pero además, para Valeriano es también imagen de la firmeza del Estado. ${ }^{66}$

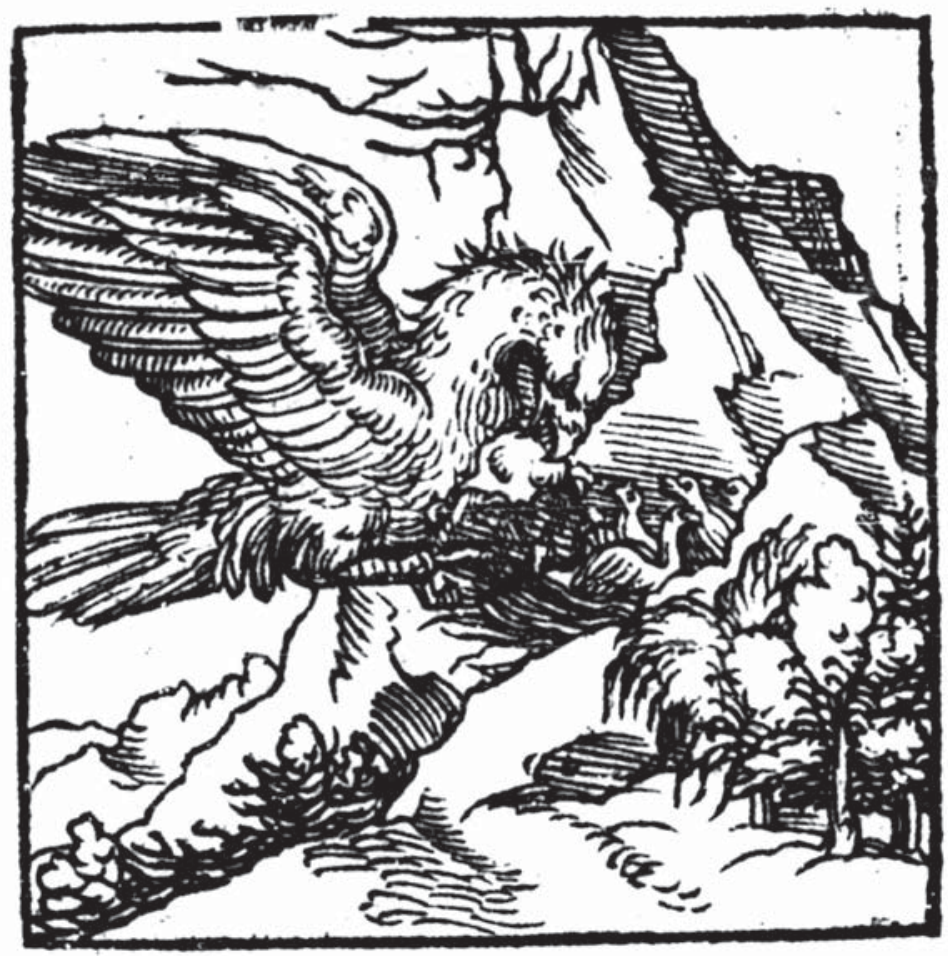

Fig. 8. Horapolo. Hieroglyphica

64. Sobre la presencia emblemática del águila colocando una piedra en su nido, véase GARCía ARRANZ, Symbola et emblemata avium..., 155-157. Además de Horapolo y Valeriano, que fueron las fuentes de Barcia en su sermón, otros autores que proponen la imagen con un sentido más bien moral son Scipione Bargagli y Joachim Camerarius.

65. Horapolo: Hieroglyphica (ed. Jesús M. a González de Zárate), Akal, Madrid, 1991, 446-447.

66. VAleriano, Hieroglyphica, Libro XIX. 
A partir de las anteriores imágenes, Barcia se aplica a la conclusión. Águila real es Carlos II, que celebra hoy en el religioso nido de su Capilla Real la festividad de san Pedro, piedra fundamental de la Iglesia. Traiga pues junto a sí la doctrina de san Pedro, para asegurar en su patrocinio el acierto en el gobierno de sus vasallos, la defensa de las venenosas serpientes de sus enemigos, y la continuidad de la monarquía. El rey deberá asentar por tanto en la piedra de Pedro y de la religión el muro firme de sus católicos reinos.

En la monarquía hispana se verán unidas en consecuencia la grandeza del palacio y la verdadera religión. ${ }^{67}$ No debe vacilar el monarca en su religión y su fe; pero tal convicción debe traducirse en hechos. Y Barcia concreta algunas situaciones en las que Carlos II debe dar muestras de su religiosidad, si bien confiesa sentirse incómodo, y si lo hace es «porque me compele la obligación de Embajador del Supremo Rey». ${ }^{68}$ Una de ellas se refiere al tratamiento que recibe la Iglesia por parte de muchos ministros de Su Majestad, en concreto de aquellos que no anhelan sino su propia ambición, pues se muestran contrarios a conceder lo que necesita para su mantenimiento, argumentando para ello «una razón que se llama Economía, que no sé cómo se llamará en el Juicio de Dios». Afirma también que con suma frecuencia se le disputa a la Iglesia su inmunidad y su libertad, entrometiéndose en la verdad de las causas eclesiásticas o reteniendo las bulas apostólicas. Y si bien no se muestra contrario a la contribución de la Iglesia a la Hacienda estatal, y en concreto al pago de los impuestos de cruzada, subsidio y excusado, ${ }^{69}$ recomienda vivamente al monarca vigilancia en su aplicación, deseándole «sea tan escrupuloso como lo fue la Señora Reina Doña Isabel».

Ninguna de las anteriores son actitudes conforme a la religión que debe profesar la monarquía. Como tampoco lo son algunas decisiones adoptadas en materia de política exterior que han llevado a alianzas con potencias herejes; en este punto su incomodidad sube de grado, aunque parece exonerar al monarca, culpando más bien a sus ministros y consejeros. ${ }^{70}$ Conozcamos la reflexión de Barcia al respecto:

¿Cómo trata España esta Religión, y esta Fe? No hablaré de la amistad con los enemigos de Dios, y de su Fe, porque no vengo a votar en Estado, sino a predicar; y ya estos señores que la votan, habrán visto en el gran Político Saavedra la Empresa noventa y tres, y lo que en varias partes de la Escritura dijo Dios.

67. Sobre la importancia de la religión en la figura de Carlos II, véase Antonio Álvarez-Ossorio Alvariño: «Virtud coronada: Carlos II y la piedad de la Casa de Austria», Política, religión e Inquisición en la España Moderna: homenaje a Joaquín Pérez Villanueva, Universidad Autónoma, Madrid, 1996, 2957; del mismo autor, «La piedad de Carlos II», Carlos II. El rey y su entorno cortesano, 141-165; y JosefinA CASTILla Soto: «Tratados para la educación del rey niño», Carlos II. El rey y su entorno cortesano, 57-60.

68. Despertador Christiano Quadragessimal de Sermones Doctrinales, t. II, 18-19.

69. Sobre el pago de estos impuestos, que constituían la principal aportación de la Iglesia al erario público, véase Henry Kamen: La España de Carlos II, Editorial Crítica, Barcelona, 1981, 354-356.

70. Como significa Negredo del Cerro para la época de Felipe IV, la crítica directa al monarca desde el púlpito no resultó frecuente; se prefirió por el contrario mantener la idealización de su persona, culpando a los ministros de la toma de decisiones equivocadas o de las desgracias que asolaban al pueblo. NeGREDO Del Cerro, Los predicadores de Felipe IV, 381-384. 


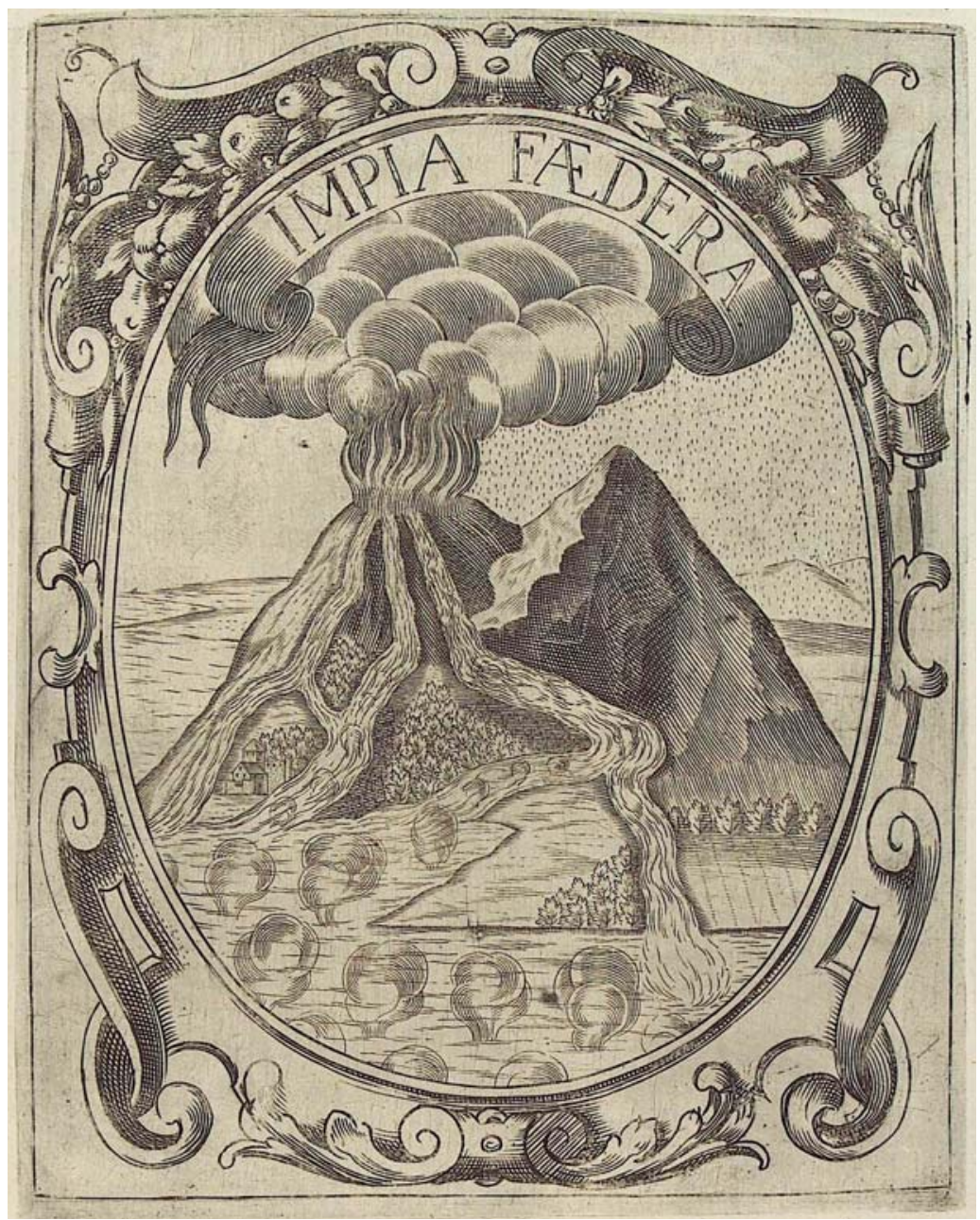

Fig. 9. Diego SaAvedra Fajardo. Idea de un Príncipe Político Cristiano. Empresa 93. Impia Foedera

Directa es la alusión a la empresa 93 de Saavedra Fajardo, que lleva por mote Impia Foedera (Alianzas impías). Muestra su pictura dos montes unidos, uno de ellos el Vesubio en erupción, arrojando por su cráter llamas, cenizas y ríos de lava que discurren por su ladera, arrasando a su paso todo cuanto encuentran hasta desembocar en el Tirreno, donde hacen hervir sus aguas [Fig. 9]. El volcán italiano, que tras permanecer inactivo durante largo tiempo destruye a quienes confiadamente se instalaron en su proximidad, recuerda a los príncipes católicos que deben evitar alianzas y confederaciones con los enemigos de la fe, pues aunque los odios que generan las diferencias religiosas pueden quedar disimulados por la necesidad presente, acaban por aflorar 
y resultan sumamente perjudiciales: «No espere menos daños el príncipe católico que se coaligare con infieles», sentencia el diplomático, quien critica duramente las alianzas de Francia con estados protestantes para hacer frente a la Casa de Austria. ${ }^{71}$

Parece evidente que Barcia, al recuperar la empresa saavedrina, pone en tela de juicio determinadas decisiones, como pudieran ser las coaliciones con Holanda e Inglaterra, los tradicionales enemigos religiosos, ante la necesidad de una política pragmática en clave antifrancesa capaz de frenar en varios frentes las apetencias hegemónicas de Luis XIV. Sin embargo, no podemos obviar que tales alianzas contribuyeron de forma decisiva a preservar casi intacta la integridad territorial de la monarquía hispana, lo cual resulta prueba evidente de que el panorama europeo estaba cambiando en esta segunda mitad del siglo XVII. ${ }^{72}$

Se trata con poco decoro a la Iglesia y a sus ministros, y se llega a alianzas con países que reniegan de la fe en Dios: «¿Es esto conforme a la religión de que nos gloriamos?», pregunta Barcia, antes de recordar nuevamente al rey con cierto tono apocalíptico que actitudes como las anteriores pueden suponer la destrucción de la monarquía. De ahí que Carlos II deba acudir pronto al remedio, mostrándose firme en su religiosidad y amparando con su protección a la institución eclesiástica, como lo hicieron sus antepasados.

La «E» de la palabra «Rey» advierte al monarca del ejemplo que debe dar con su comportamiento a sus súbditos, quienes se mirarán en él como si de un espejo se tratara. En efecto, «espejo es el monarca en que se mira todo el orbe español», y debe serlo reluciente y sin mancha, pues «en V. Majestad tenemos todos sus amantes vasallos grandes ejemplos de virtudes que mirar, y que imitar». La idea del monarca como espejo de virtudes queda recogida en la empresa 33 de las Empresas Políticas de Saavedra Fajardo, en la que con el mote «Siempre el mismo» aparece un león rampante mirando a un espejo quebrado en dos partes, cada una de las cuales refleja su figura completa; quiere significar con ello que el rey debe mantener su virtud en toda circunstancia, ya sea próspera o adversa, pues es modelo de conducta para su pueblo ${ }^{73}$ [Fig. 10].

Resulta digno de mención el hecho de que en este punto Barcia conmina vivamente a Carlos II a tomar medidas en dos temas muy concretos. El primero, que elimine todo gasto superfluo derivado de las fiestas de la Corte con

71. SAAVEdra FAJARdo, Empresas políticas, 966-972. GonZÁlez de ZÁRATE, «Análisis de las Empresas Políticas...», 104-105.

72. Acerca de las relaciones hispano-holandesas en este período, véase DAVID SALINAS: «La diplomacia española a través de los embajadores en La Haya (1665-1700)», Bulletin Hispanique, n. ${ }^{\circ}$ 90, 1988, 363 374; del mismo autor, La diplomacia española en las relaciones con Holanda durante el reinado de Carlos II (1665-1700), Ministerio de Asuntos Exteriores, Madrid, 1990; Manuel Herrero Sánchez: Las Provincias Unidas y la Monarquía Hispánica (1588-1702), Arco Libros, Madrid, 1999; y del mismo autor, El acercamiento hispano-neerlandés (1648-1678), CSIC, Madrid, 2000.

73. SAAVEdra FAJARdo, Empresas políticas, 450-460. GonZÁlez de ZÁRATE: «Análisis de las Empresas Políticas...», 43. 


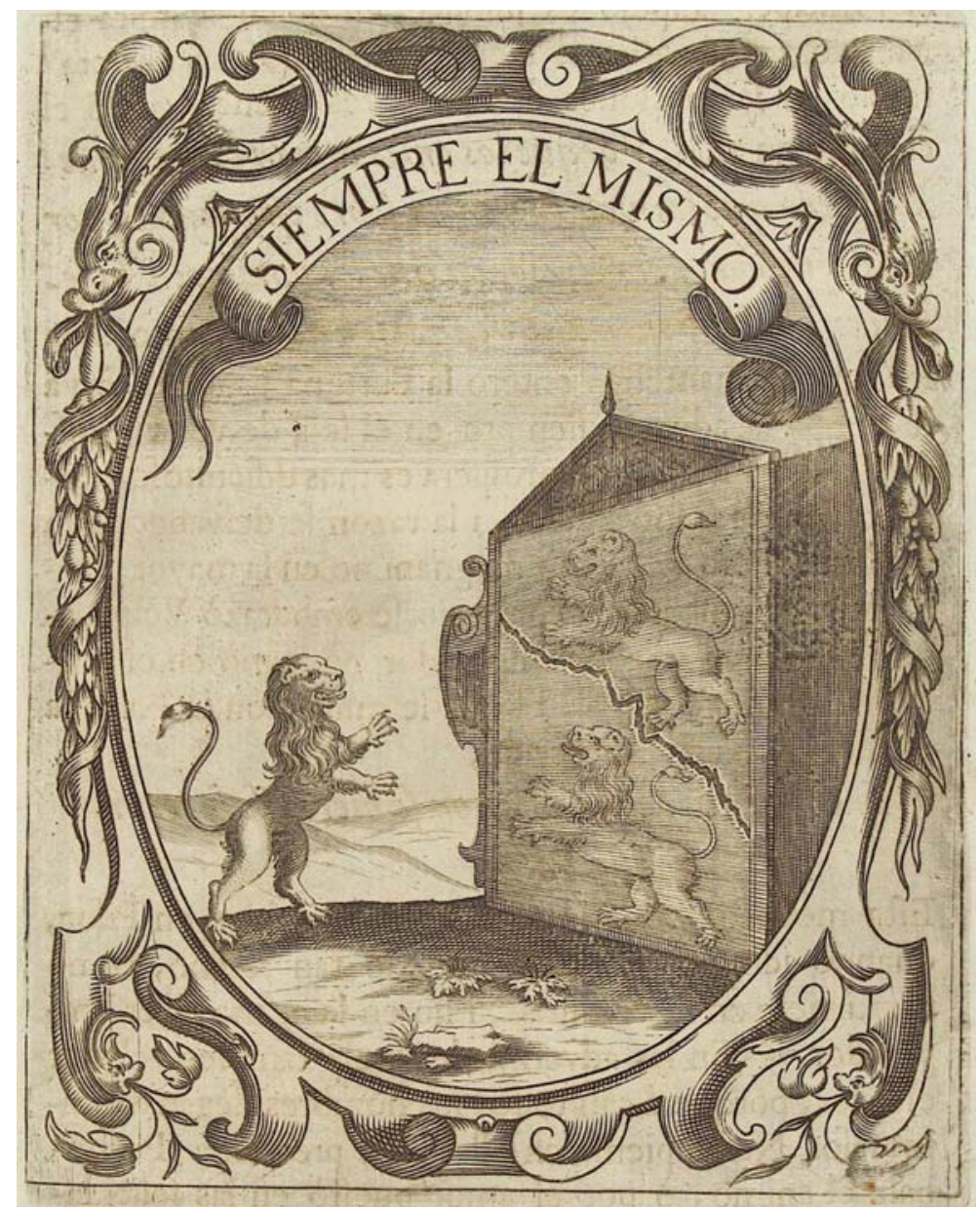

Fig. 10. Diego SaAvedra Fajardo. Idea de un Príncipe Político Cristiano. Empresa 33. «Siempre el mismo»

que «se destruye insensiblemente el oro y plata de esta Monarquía». ${ }^{74}$ Se trata de un argumento que ya había hecho acto de presencia en otros predicadores reales del siglo XVII, como podemos comprobar en el sermón predicado por el jesuita Jerónimo de Florencia en las honras fúnebres de Felipe III en los Jerónimos en $1621 .{ }^{75} \mathrm{El}$ segundo, que acometa una reforma de la moda cortesana, pues «con ese adorno superfluo y desnudez escandalosa que se usa en

74. En efecto, una de las más importantes polémicas surgidas durante el reinado de Carlos II alrededor de la organización de fiestas cortesanas fue la del gasto superfluo, coincidiendo con un período de profunda crisis económica. Las advertencias al monarca sobre la necesidad de atemperar los gastos se suceden desde muy diferentes ámbitos, y tanto Carlos II como los Consejos dieron muestras de intentar adecuar las circunstancias festivas a la desfavorable coyuntura económica. CARMEN SANZ Ayán: «La fiesta cortesana en tiempos de Carlos II», Carlos II. El rey y su entorno cortesano, 241-268.

75. Negredo Del CERRo, «Servir al rey y servirse del rey...», 373. 
los trajes, se siguen lamentables muertes de muchas almas, consumo de los caudales que son sangre de los reinos, y corrupción del valor y costumbres de los españoles». Se refiere con toda probabilidad al hecho de que, si bien España siguió aferrada a sus formas de vestir tradicionales durante gran parte del siglo XVII, caracterizadas por la sobriedad y austeridad, no resultó por completo impermeable a la influencia francesa, que se concretó en el reinado de Felipe IV en la introducción del guardainfante femenino -cuyo escote se acentuó en las últimas décadas del siglo XVII-, y en el de Carlos II en la importación de la pomposa y vistosa moda civil masculina aristocrática; de ahí que la crítica no sea solo al carácter profano de los trajes, sino al hecho de que con la importación de dicha moda «se enriquece a los Reinos extranjeros, que llenan a España de invenciones de oropel, y se llevan el oro de sus Indias». ${ }^{76}$

Considera el orador que la vanidad y descompostura en el vestir son la causa de los numerosos males que afligen al reino, desde las guerras y hambres, hasta las pestes y terremotos; por lo que, desterrando el monarca de palacio el carácter profano de la moda, el pueblo seguirá su ejemplo y retornará a la honestidad en su indumentaria y costumbres, y Dios corresponderá con su misericordia. ${ }^{77}$ La necesaria restauración de costumbres para volver a gozar del favor divino es tema recurrente en los predicadores reales del siglo XVII, quienes exigían la decidida actuación del monarca para que se preocupase más de los valores morales que de una práctica política que quedaría en nada sin la corrección de actitudes. ${ }^{78}$

En su obligación como ejemplo y modelo de conducta para sus súbditos, Carlos II deberá guiarse siempre por el dictado de la verdad. El evangelio de la enseñanza de Jesús a los judíos sobre la verdad (Jn 8, 39-47) le sirve a Barcia para profundizar en el ejercicio de dicha virtud..$^{79} \mathrm{Afirma}$ en primer lugar que el príncipe debe poner sumo cuidado en conocer la verdad, pues aunque muchos ministros y consejeros parecen actuar movidos por ella, es en realidad la ambición la que les empuja. Esté por tanto prevenido en examinar la verdadera rectitud de intenciones; $y$, partiendo de la sentencia de los Proverbios 30, 28 («El lagarto, que se atrapa con las manos, mora en los palacios reales»), pone el ejemplo de la empresa 48 de Saavedra Fajardo, que lleva por mote Sub luce lues

76. Me remito para este asunto a Ruth De la Puerta Escribano: «La moda civil en la España del siglo XVII: inmovilismo e influencias extranjeras», Ars Longa, n. ${ }^{\circ} 17,2008,67-80$.

77. Es tal la preocupación del predicador real por los trajes profanos que dedicará íntegramente a este asunto el sermón cuadragésimo primero de su Despertador Christiano de Sermones Doctrinales, al hallar «en lo más florido de la cristiandad un uso o abuso de vestir ricamente, profanamente, y aun escandalosamente». En este caso se sirve de una nueva empresa de Saavedra Fajardo que lleva por mote Merces belli (La recompensa de la guerra) y muestra un león muerto tendido en el suelo de cuya boca salen abejas. El león abatido por Sansón en cuya boca las abejas hicieron un panal de miel servía al diplomático murciano para advertir al monarca que solo para sustentar la paz tenía sentido la guerra; en cambio, Barcia se aleja de la interpretación original para indicar el rigor o la dulzura con que se conducirá el Señor en el Juicio Final según el comportamiento en el vestir. Despertador Christiano de Sermones Doctrinales, t. II, 320-346.

78. Negredo del Cerro, Los predicadores de Felipe IV, 348-357.

79. Ibídem, 368-377. 
(Bajo la luz, corrupción). Protagoniza su pictura un estelión o salamanquesa con su piel recubierta de manchas que brillan como estrellas en la luz, pero que ocultan veneno en su pecho [Fig. 11].

La enseñanza que se extrae es que el príncipe debe estar advertido contra lisonjeros y aduladores que, bajo atractiva apariencia, ocultan dañosa intención y mudan de parecer según les conviene; de manera que si para el diplomático murciano «no todo lo que reluce es por buena calidad del sujeto», para el predicador real «no todo lo que parece oro lo es».$^{80} \mathrm{El}$ príncipe no recibe de los hombres sino adulación y engaño; la verdad tan solo procede de Dios, y deberá mostrar sumo cuidado en ponerla en práctica de inmediato para lograr el fruto de la salvación de su alma y de las de sus vasallos, concluye Barcia. ${ }^{81}$

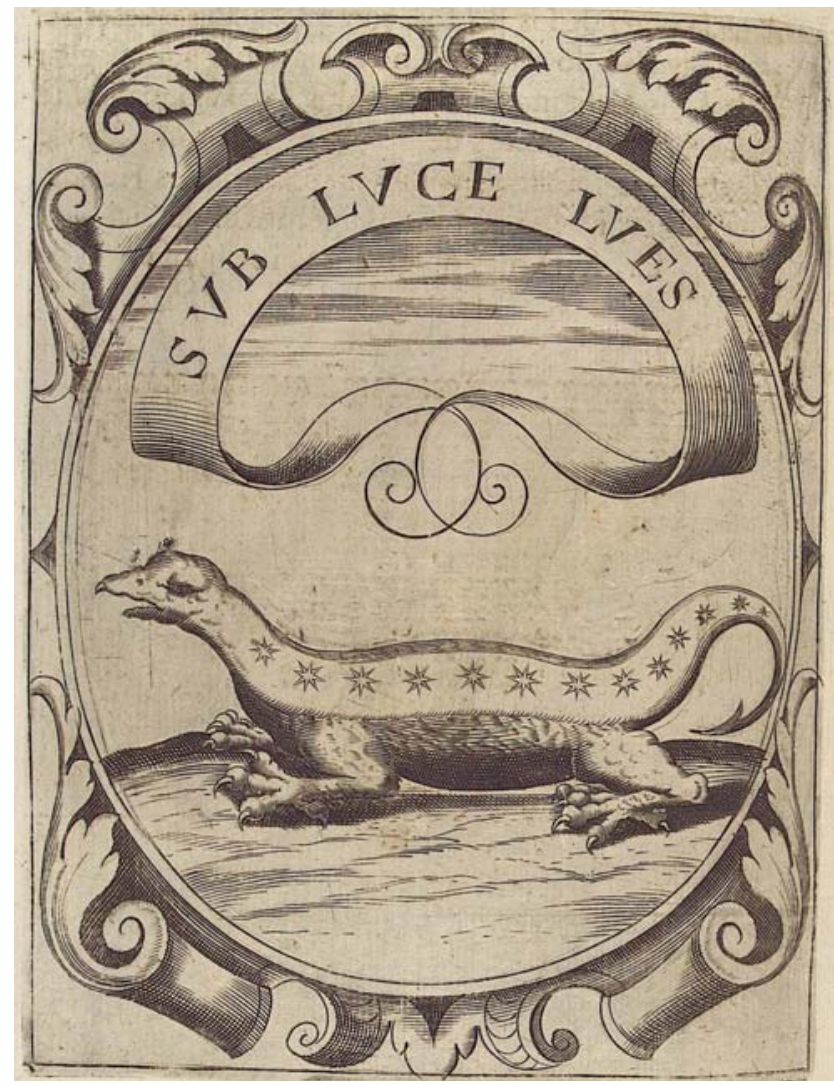

Fig. 11. Diego Sanvedra Fajardo. Idea de un Príncipe Político Cristiano. Empresa 48. Sub luce lues

80. SaAvedra Fajardo, Empresas políticas, 565-578. GonZÁlez de ZÁrate, «Análisis de las Empresas Políticas...», 66-67.

81. La asociación del estelión con el engaño y la adulación tiene su origen en la Historia natural de Plinio y figura en diversos repertorios emblemáticos, entre ellos el de Alciato, cuyo emblema In fraudulentos (Sobre los embaucadores) protagoniza dicho reptil para moralizar acerca del engaño y la envidia. José JuLIO García ARRAnZ: «La salamandra: distintas interpretaciones gráficas de un mito literario tradicional», Norba-arte, n. ${ }^{\circ} 10,1990,53-68$. 
Finalmente, la «Y» de la palabra «Rey» recuerda a Carlos II la práctica de la justicia, virtud eminentemente social a la que define el predicador real como «la columna que sustenta sobre sí todo el edificio grande de la Real Felicidad, sin la cual se arruina fácilmente». $\mathrm{Al}$ rey, más que a ninguna otra persona, le corresponde aplicar la justicia en términos de equidad, utilizando su sabiduría para rodearse de las personas idóneas que le puedan aconsejar en dicha materia y aparecer ante sus súbditos como el primer observante de las leyes. ${ }^{82}$ No parece sin embargo que el monarca mostrase excesiva inclinación hacia ella, como se desprende de diversos testimonios, entre ellos el del embajador veneciano Giovanni Cornaro a comienzos de la década de 1680, afirmando que no se reservaba la jurisdicción del premio y el castigo, de manera que recurrir a él con instancias era lo mismo que llevarlas a su estatua. ${ }^{83}$ Semejantes declaraciones nos dan la clave para interpretar las continuas exhortaciones a la justicia que incluye Barcia en sus sermones regios. ${ }^{84}$

En el predicado el Lunes Santo de 1688 significa que la eficacia de la monarquía descansa en el crédito de su justicia y, sirviéndose de dos imágenes del Mundus Symbolicus de Picinelli (Ab alio regimen, In horologio Achaz), recuerda al monarca que en esta materia debe actuar como reloj de sol y no como reloj de ruedas. ${ }^{85}$ Ambos son metáfora de la justicia, pues en el orden y concierto con que dan las horas, se advierte el dar a cada uno lo que le corresponde; mas el reloj mecánico está sujeto a la voluntad de quienes lo cuidan, que pueden adelantarlo, atrasarlo o detenerlo, y así también, el monarca puede errar en la administración de justicia si deposita toda su confianza en los ministros que lo asisten, movidos en muchos casos por su propio interés y beneficio ${ }^{86}$ En cambio, el reloj de sol se gobierna por un espíritu superior como es el astro rey, de manera que no hay industria humana capaz de adelantar, atrasar o detener sus horas; y esta es imagen de la perfecta justicia de Carlos II, quien deberá ejercerla atendiendo a la luz superior que es Dios, sin permitir que nadie se interponga en su resolución. La imagen del reloj de sol

82. Castilla Soto, «Tratados para la educación del rey niño», 60.

83. LuIs Riвot: «El rey ante el espejo. Historia y memoria de Carlos II», Carlos II. El rey y su entorno cortesano, 23.

84. No fue Barcia el único predicador real de su época que insistió en la importancia que adquiría la justicia en el gobierno de la monarquía. También el franciscano descalzo fray Francisco de Santa Clara, en un sermón predicado a Carlos II en la Capilla Real el día del Santísimo Sacramento del Altar de 1692, examinaba con particular atención la virtud política de la justicia distributiva y la necesidad de que el monarca regulase la acción de dar y distribuir beneficios conforme a los méritos y no al nacimiento. Álvarez-Ossorio Alvariño, «Facciones cortesanas y arte del buen gobierno...», 113.

85. Despertador Christiano Quadragessimal de Sermones Doctrinales, t. III, 150-158. El reloj es una imagen sumamente recurrida en el imaginario barroco, asociado en muchas ocasiones al poder y al funcionamiento del Estado. Barcia muestra especial predilección por el símil del reloj al emplearlo en situaciones muy diferentes, tomando siempre como referencia el Mundus Symbolicus de Filippo Picinelli. Al igual que el predicador real, también Núñez de Cepeda combina en su empresa Regit et corrigit (Rige y corrige) los relojes mecánico y de sol, retomando la tradición ideográfica española sobre el reloj como imagen del aparato de gobierno, aplicada en este caso al prelado y su necesidad de un director espiritual. Rafael García Mahíques: Empresas Sacras de Núñez de Cepeda, Ediciones Tuero, Madrid, 1988, 78-81.

86. Picinelli, Mundus Symbolicus, Libro XXI, cap. x, n. ${ }^{\circ} 134$. 
queda así asociada a la inmutabilidad divina en la que debe fiar el monarca todas sus acciones, frente al carácter inconstante de cuanto le rodea.

Un año más tarde, el Viernes Santo de 1689, el Sermón de la Soledad de María se convierte en el marco en el cual Barcia alecciona nuevamente a Carlos II acerca de la justicia. ${ }^{87}$ La soledad y tristeza que embargaron a María al contemplar el cuerpo sin vida de su amado Hijo, son las que siente al ver a su amado reino de España carente de la aplicación de la justicia, por cuanto «si falta en un reino el alma de la justicia, será cuerpo sin alma, y morirá el reino». En esta ocasión, el orador establece un símil entre el reino y la cítara, instrumento musical en el que si las cuerdas suenan unidas a un mismo fin, conservará su acorde armonía; de ahí que tanto Valeriano como Picinelli fuentes citadas por Barcia- la propongan como jeroglífico de fidelidad en las acciones, y del concierto entre los hombres que unen sus voluntades para lograr un objetivo común ${ }^{88}$ [Fig. 12].

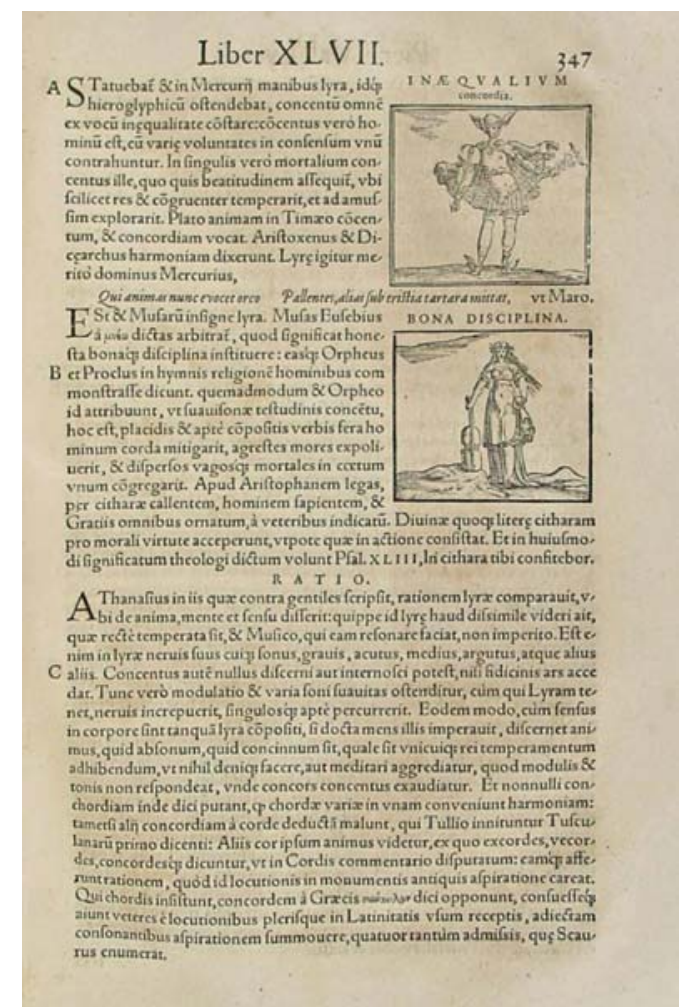

Fig. 12. Piero Valeriano. Hieroglyphica. Libro XLVII

87. Despertador Christiano Marial de varios sermones de María Santísima Nuestra Señora en sus Festividades (ed. Madrid, 1727), 236-245.

88. Valeriano: Hieroglyphica, Libro XLVII. Picinelli, Mundus Symbolicus. Libro XXIII, cap. I, n. ${ }^{\circ} 4$. 
Cítara es el reino en el que las cuerdas de la justicia constituyen su alma; pero algunas suenan de manera disonante debido a la ambición e interés particular. El rey, como soberano músico a quien corresponde pulsar las cuerdas del instrumento de la monarquía, deberá en primer lugar templarlas y sustituir aquellas que desafinan por otras que ni excedan ni falten en la administración de la justicia, contribuyendo con rectitud al bien público; $y$, a continuación, lograr la armonía haciendo que todas ellas suenen en unión y conformidad mediante la correcta aplicación de la justicia. La imagen ofrece evidentes resonancias de la empresa 61 de Saavedra Fajardo, que con el lema Maiora minoribus consonant (Las cosas más grandes están en consonancia con las más pequeñas), muestra un arpa en cuya parte superior descansa una corona $^{89}$ [Fig. 13]. El arpa es el gobierno monárquico, y su tañedor el rey, que debe buscar con la verdadera justicia la armonía entre todas las cuerdas del instrumento o estamentos del Estado..$^{00}$

La unión y conformidad en procurar el bien común resultan fundamentales en materia de justicia, insiste Barcia; y para confirmar su aserto, se apoya en una nueva imagen emblemática, tomada en esta ocasión de la Emblemata centvm, regio politica de Juan de Solórzano Pereira, en concreto en el emblema xCV, que lleva por mote Concordia quos unit, munit (La concordia protege a quienes une) [Fig. 14]. En él aparecen varios soldados provistos de lanzas y escudos que conforman una especie de muralla humana para salvaguardar una ciudad, dando a entender que no hay defensa tan firme como los ánimos y fuerzas de los ciudadanos unidos y concordes; la verdadera muralla de un Estado es la concordia entre sus súbditos, ya que en ella encontrará el príncipe su más segura defensa. ${ }^{91}$ Aplíquese por tanto el monarca en el ejercicio de la justicia mediante la elección de ministros dispuestos a trabajar por el bien común, pues solo de esta manera podrá mantenerse unido el reino de España, para alabanza de Dios y felicidad de sus vasallos, concluye el predicador.

89. SaAvedra Fajardo, Empresas políticas, 717-724. GonZÁlez de ZÁrate, «Análisis de las Empresas Políticas...», 34-35.

90. La idea de consonancia o armonía que debe observar el monarca simbolizada en el arpa es también recogida en el libro de emblemas Séneca Juez de sí mismo, de Francisco de Zárraga. FrAnCisco De ZÁrraga: Séneca Juez de sí mismo, impugnado, defendido y ilustrado. En Burgos: Por Juan Viar, y a su costa. Año de 1684, 285. Asimismo, Juan Baños de Velasco, en su obra L. Anneo Seneca ilustrado, muestra en su emblema 8 (Ruptae non sonant, Cuando están rotas no suenan) la imagen del rey sentado en un trono bajo dosel y tañendo la vihuela, para significar el equilibrio y armonía que deben presidir las decisiones reales en materia de justicia. Juan Baños de Velasco: L. Anneo Seneca ilustrado. Madrid: Mateo de Espinosa y Arteaga, 1670, 128-149. Y con el mismo significado de concordia aparece en el emblema XCVII de la Emblematum Ethico-politicorum Centuria de Zincgreff.

91. Jesús M. a GonzÁlez de ZÁrate: Emblemas Regio-Políticos de Juan de Solórzano, Ediciones Tuero, Madrid, 1987, 202-203. 


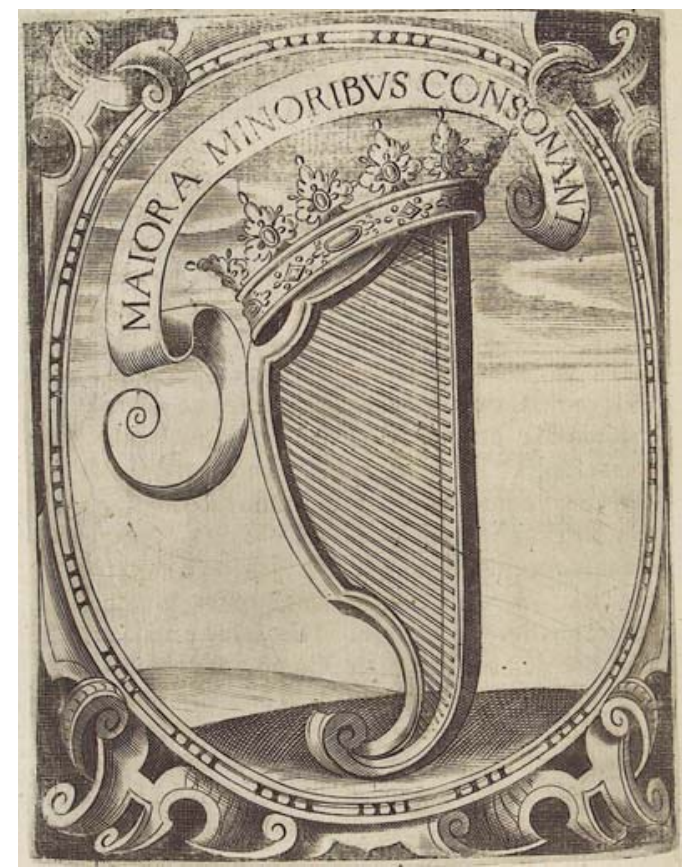

Fig. 13. Diego SaAvedra Fajardo. Idea de un Príncipe Político Cristiano. Empresa 61. Maiora minoribus consonant

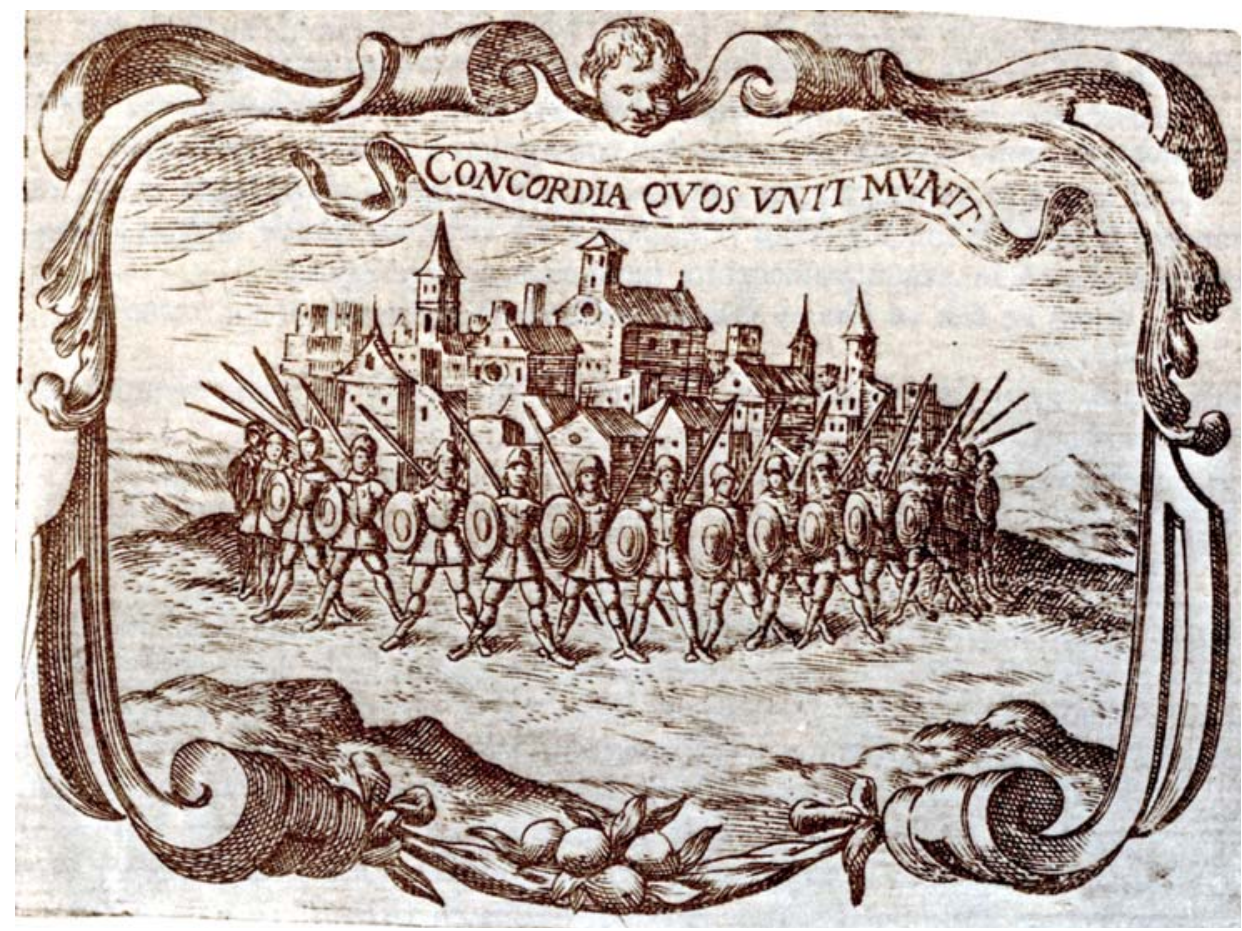

Fig. 14. Juan De Solórzano Pereira. Emblemata centvm, regio politica. Emblema XCV. Concordia quos unit, munit 


\section{LA SUCESIÓN AL TRONO}

No elude José Barcia un asunto de capital trascendencia en el reinado de Carlos II, como es la sucesión al trono. Lo hace siempre desde una perspectiva cristiana, exhortando al monarca a que extreme su piedad y celo litúrgico para ganarse la benevolencia de la corte celestial, en particular mediante la devoción a la Inmaculada y el culto al misterio del altar. ${ }^{92}$ Tal postura resulta coherente si tenemos en cuenta que, entre los rasgos predominantes de la Pietas Austriaca, destacaban la veneración de la Virgen en el misterio de su Inmaculada Concepción, y la devoción a la Eucaristía; así queda ejemplificado en el grabado de Pedro de Villafranca que ilustraba la obra Reynados de menor edad, y de grandes Reyes (Madrid, 1672) de Francisco Ramos del Manzano, preceptor de Carlos II, el cual muestra a la reina Mariana de Austria y a su hijo, sentados frente a frente: ella sostiene la corona para indicarle que, en el marco del providencialismo divino, ha de poner su esperanza en el patrocinio de la Inmaculada y en la veneración del Santísimo Sacramento, motivos representados en sendos marcos de la pared del fondo [Fig. 15]. ${ }^{93}$

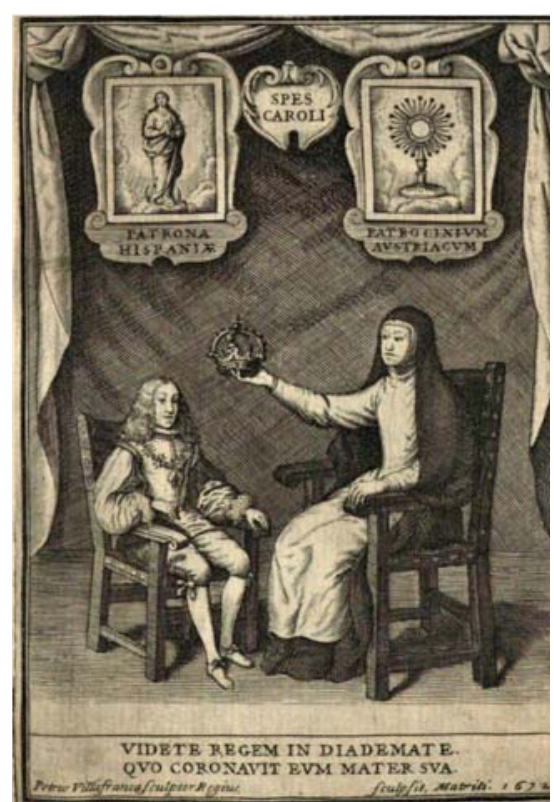

Fig. 15. Pedro De Villafranca. Grabado de Reynados de menor edad, y de grandes Reyes (Madrid, 1672), de Francisco Ramos del Manzano

92. A la doble vía - devocional y exorcismos- que siguió Carlos II ante la falta de sucesión al trono alude Álvarez-Ossorio Alvariño, «La piedad de Carlos II...», 147. Véase también al respecto MAR Rey Bueno: El Hechizado. Medicina, alquimia y superstición en la corte de Carlos II (1661-1700), Ediciones Corona Borealis, Madrid, 1998.

93. Alfonso Rodríguez G. De Ceballos: «Retrato de Estado y propaganda política: Carlos II (en el tercer centenario de su muerte)», Anuario del Departamento de Historia y Teoría del Arte, vol. xII, 2000, 93-109. 
Precisamente la Pietas Eucharistica es el asunto del sermón predicado el 28 de mayo de 1690 a los nuevos esposos Carlos II y Mariana de Neoburgo. ${ }^{94}$ Se trata de una homilía compleja -advierte el predicador al inicio que va a descubrir «un symbolo, y Hierogliphico soberano de este Real Desposorio»-, a lo largo de la cual subyace un vivo sentimiento de poder lograr la tan ansiada descendencia, que se concreta en expresiones como "presagio feliz», «dilatadas esperanzas», «feliz anuncio» o «esperanza muy viva», entre otras. Barcia se sirve continuamente de juegos de palabras, como el que hace con los nombres de los reyes, Carolus (que traduce como «carne en pan») y María Ana («penitencia y gracia»), para convertirlos en imagen del desposorio espiritual de Jesús Sacramentado con el alma, y de la preparación de la penitencia y la gracia para la unión de la Esposa con el Divino Cordero. Y recoge también un anagrama cuya autoría atribuye a «un ingenio de esta Corte» compuesto en obsequio de la nueva reina con motivo de su llegada, en el que el nombre de «Maria Anna de Neoburgo» quedaba transformado en Dabo annua munera regi $9^{95}$ de tal manera que «el nombre mismo de Nuestra Augustísima Reina promete en este desposorio la Real fecunda sucesión, para hacer perpetua en esta Católica Monarquía la felicidad», concluye.

Mas para que esta esperanza llegue a verse convertida en feliz acontecimiento, es necesario el auxilio de la gracia divina; y en este punto introduce el símil de la palmera, deteniéndose en dos cualidades de este árbol. ${ }^{96}$ Una de ellas se concreta en el hecho de que en las palmeras hay esposo y esposa, y la primera solo fecunda a la segunda cuando crecen una al lado de la otra y entrelazan sus raíces bajo tierra, logrando así el fruto deseado. La segunda, son sus hojas cortantes, como si de espinas o cuchillos agudos se tratase. Pues bien, en el primer caso la palmera se convierte en metáfora del matrimonio, tal y como lo propone Pierio Valeriano en sus Hieroglyphica $;{ }^{97}$ pues al igual que una se inclina hacia la otra para obtener el fruto, así también la unión y fidelidad entre los esposos supondrán la recompensa de la descendencia. En cuanto a las hojas afiladas, para Barcia simbolizan los cuchillos con los que, no ya solo los monarcas, sino todos sus súbditos, deben hacer frente al pecado: «Haya filo de palma resolución y cristiano celo para cortar escándalos, abusos, ambiciones y vicios en lo común; y nos concederá Dios la sucesión real deseada», asegura el predicador.

94. Despertador Christiano Divino, y Eucharistico, de varios sermones de Dios Trino, y Uno (ed. Madrid, 1695), 393-401.

95. Al anagrama dedicado a la segunda esposa de Carlos II aludirá igualmente el jesuita JUAN GARCíA DE VARGAS: Elicidata Grammatica latina ad strictam artem redacta. Matriti: apud D. Gabrielem de Barrio, Anno MDCCXI, 333-334.

96. Sobre el simbolismo de la palmera, véase José MAnuel DíAz DE Bustamante: «Onerata resurgit. Notas a la tradición simbólica y emblemática de la palmera», Helmantica: Revista de filología clásica y hebrea, t. XXXI, n. ${ }^{\circ}$ 94, 1980, 27-88; y PEDRO A. GALERA ANDREU: «La palmera, arbor victoriae. Reflexiones sobre un tema emblemático», Goya, n. ${ }^{\circ}$ 187-188, 1985, 63-67. A las propiedades de fecundidad atribuidas tradicionalmente a la palmera se refiere asimismo ANA VALTIERRA LACALLE: «Que ha de resistir el apremio. Sobre lo simbólico de la palmera en el mundo griego», Emblemata, n. ${ }^{\circ} 11,2005,29-58$.

97. VAleriano, Hieroglyphica, Libro L. 
En definitiva, una vida plena de gracia y firmeza contra los vicios, en la que los reyes se conduzcan con piedad, justicia y fortaleza, es la receta de Barcia a los nuevos esposos «para que reinen V. Majestades en su monarquía católica con sucesión dilatada». No es de extrañar por tanto que desde el primer momento de su estancia en España, la nueva reina tuviese una idea obsesiva: dar un heredero a la Corona. ${ }^{98}$ No solo los emblemas y jeroglíficos que adornaron las decoraciones efímeras erigidas con motivo de su entrada en Madrid aludían a la deseada descendencia, ${ }^{99}$ sino que hasta los predicadores reales se encargaban de recordárselo desde el púlpito apenas recién llegada a la Corte.

\section{LA CERTEZA DE LA MUERTE Y SU PODER IGUALADOR}

Los sermones predicados en tiempo de Cuaresma resultan propicios para aleccionar al monarca acerca de la certeza de la muerte. El sermón en San Jerónimo el miércoles de ceniza de 1689, en memoria de María Luisa de Orleans, constituye toda una lección acerca de la muerte y el desengaño, en la que se suceden imágenes que actúan como memento mori para el monarca. ${ }^{100}$ La primera de ellas es el propio recordatorio de la muerte de la reina: «No he menester elocuencia, para predicar a la Corte, cuando hay en la Corte polvo que predica, con su profundo elocuente silencio, las más alta lección de desengaño», comienza.

Barcia recuerda a continuación que la ceniza de este día convierte el cristal de la memoria en espejo para que, mirándose el monarca en él, asuma que es tierra y corrija las manchas que afean su alma, sin tener que lamentarse cuando llegue la hora de la muerte. El espejo como símbolo del propio conocimiento es empleado con relativa frecuencia por Barcia en sus sermones, remitiéndose para ello al emblema de Alciato que lleva por mote Dicta septem sapientum (Los dichos de los siete sabios), en el que uno de ellos, Quilón el Espartano, tenía este objeto por divisa, y era su sentencia el conocimiento propio: Noscete ipsum (Conócete a ti mismo) ${ }^{101}$ [Fig. 16]. No falta tampoco la comparación de la vida del hombre con el curso de los ríos que desembocan en el mar, desde los más humildes a los de inmenso caudal, sin distinción alguna, en clara referencia al poder igualador de la muerte, que ni siquiera perdona a los poderosos de la tierra.

98. Así lo estima José Calvo Poyato: Carlos II el Hechizado y su época, Planeta, Madrid, 1991, 128.

99. Es el caso del primer jeroglífico que formaba parte de la decoración levantada alrededor de la fuente de la plazuela de la Villa, que mostraba al viento Austro, personificado en un joven volando y soplando contra una nube, de la que brotaba la lluvia con que se fecundaba un jardín, en alusión a la ansiada descendencia real. Zapata Fernández de la Hoz, «La entrada de María Ana de Neoburgo...», 266-267.

100. Despertador Christiano Quadragessimal de Sermones Doctrinales, t. I (ed. Cádiz, 1697), 35-44.

101. Alciato, Emblemas, 229-230. 


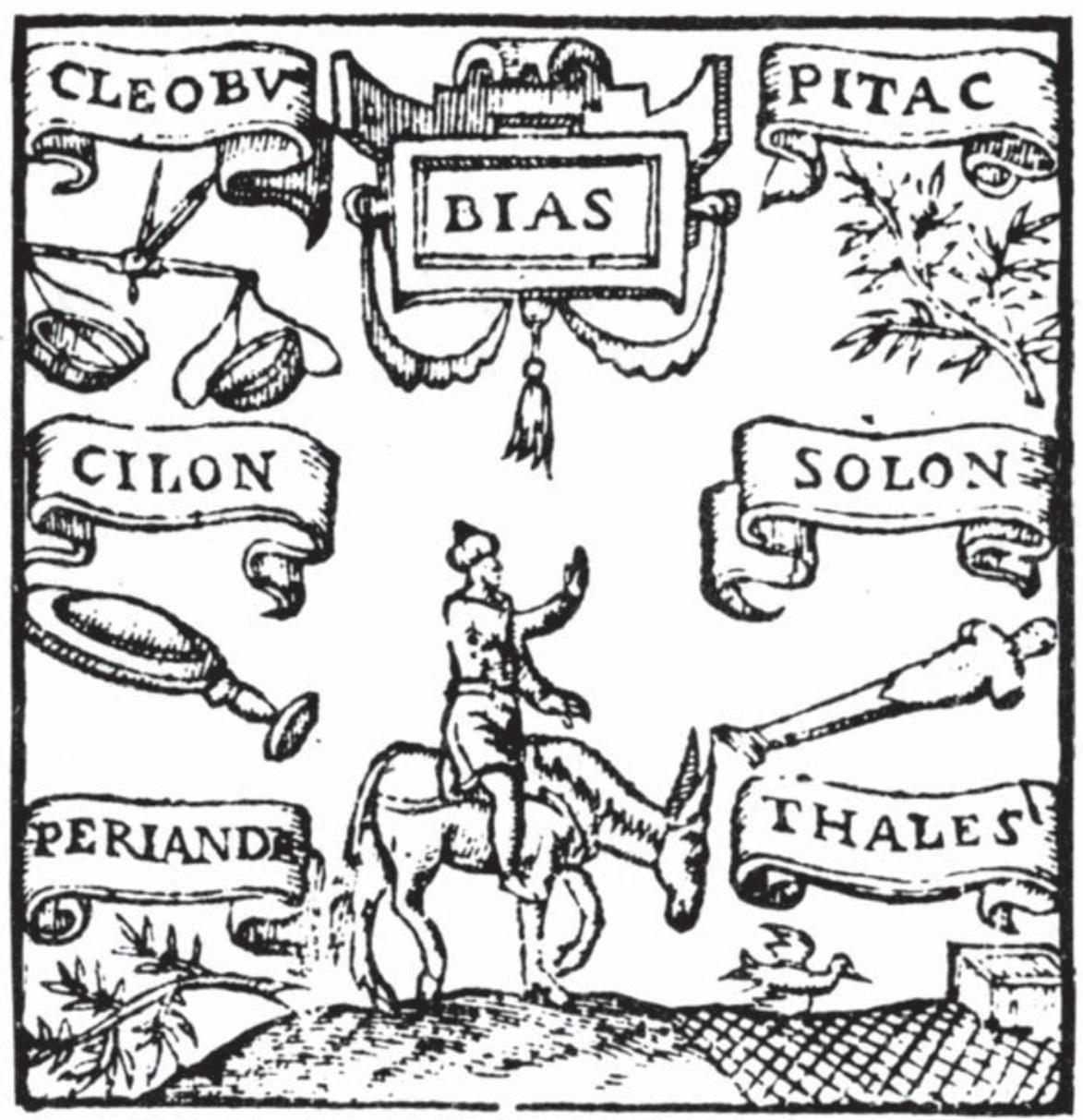

Fig. 16. Alciato. Emblematum libellus. Dicta septem sapientum

Un año más tarde, de nuevo la predicación del miércoles de ceniza sirve a Barcia para «representar» una auténtica «escena de vanitas». En efecto, afirma haber llegado hasta la Capilla Real para presentar ante el monarca un memorial solicitando plaza en cualquiera de los Consejos de Su Majestad para la Muerte, universal consejera que le aseguraba los mayores aciertos; pues recuerda al rey que es hombre, para que refrene sus apetitos; que es tierra, para que como rey la cultive; y que es polvo, para que gobierne con acierto. Admita Carlos II como consejera a la Muerte, «porque admitida en sus reales Consejos alcanzará a ser un perfecto rey, pues es medio para vivir como rey justo y para pasar de una muerte dichosa a la eterna corona de la gloria», concluye. ${ }^{102} \mathrm{Un}$ consejo similar había dado Jerónimo de Florencia a Felipe IV en el sermón de 
exequias de Felipe III, al instar al nuevo monarca a que tuviera un criado que desempeñara diversos oficios palatinos, entre ellos los de consejero de Estado y presidente de su Consejo y Real Hacienda; mas este criado no era otro que «el temor de la muerte». ${ }^{103}$

\section{LA PREDICACIÓN DE BARCIA A LOS CONSEJOS DE SU MAJESTAD}

Igual que a Carlos II y a la familia real, también José Barcia se dirigió a quienes conformaban el gobierno de la monarquía hispana. Entre 1688 y 1691 contamos un total de veintiún sermones dirigidos a los diferentes Consejos de Su Majestad, cuya predicación tuvo lugar en las iglesias madrileñas en las que acostumbraban a celebrar el culto: el Consejo de Castilla, en el desaparecido convento franciscano de San Gil; el de Indias, en el de Nuestra Señora del Carmen; el de Flandes, en el Real Oratorio del Caballero de Gracia; los de Hacienda y de Cruzada, en la Casa Profesa de la Compañía de Jesús; el de la Inquisición, en el monasterio de Santo Domingo el Real; y el Consejo de Órdenes, en el convento de la Concepción Francisca.

Como no podía ser de otra manera, la doctrina que transmite Barcia a los Consejos se encuentra en total sintonía con el ideal del príncipe políticocristiano con que trata de modelar a Carlos II. A todos ellos pretende inculcar una serie de valores comunes, comenzando por las cualidades que deben adornar al perfecto consejero, como son noticia y ciencia de los asuntos que le competen, benevolencia y rectitud de intención, y libertad para dar su opinión y ejecutar su voto. El buen consejero será como el mecanismo de un reloj, en todo momento en funcionamiento para que el monarca acierte a dar la hora en punto, imagen tomada de Picinelli y de Saavedra Fajardo, quien en la empresa 57 de sus Empresas Políticas recoge, con el mote Uni reddatur (Sea reducido a uno solo), un reloj de mesa como metáfora del gobierno en el que la maquinaria son los ministros y las agujas el propio príncipe ${ }^{104}$ [Fig. 17]. Deberá velar por el orden interno y mantener la unidad con los restantes miembros del Consejo, de tal forma que todos ellos dirijan sus acciones al unísono guiados por la luz de la razón cristiana; no en vano, las discordias domésticas no harán sino allanar el camino a los enemigos exteriores de la monarquía, idea muy en consonancia con el pensamiento saavedrino. Y se hará patente en él su desvelo por el bien público, pues al igual que la candela se gasta por alumbrar, así también el ministro deberá obligarse en el cumplimiento de su función, olvidando su descanso y su interés particular. Picinelli vuelve a ser una vez más su fuente de inspiración. ${ }^{105}$

103. NEGREDO DEL CERRO, «Servir al rey y servirse del rey», 373.

104. Picinelli, Mundus Symbolicus, Libro XXI, cap. X, n. ${ }^{\circ} 114$. SaAvedra Fajardo, Empresas políticas, 663-674. GonzÁlez de ZÁrate, «Análisis de las Empresas Políticas», 79-80.

105. PiCinelli, Mundus Symbolicus, Libro XV, cap. vi, n. ${ }^{\circ} 42$. 


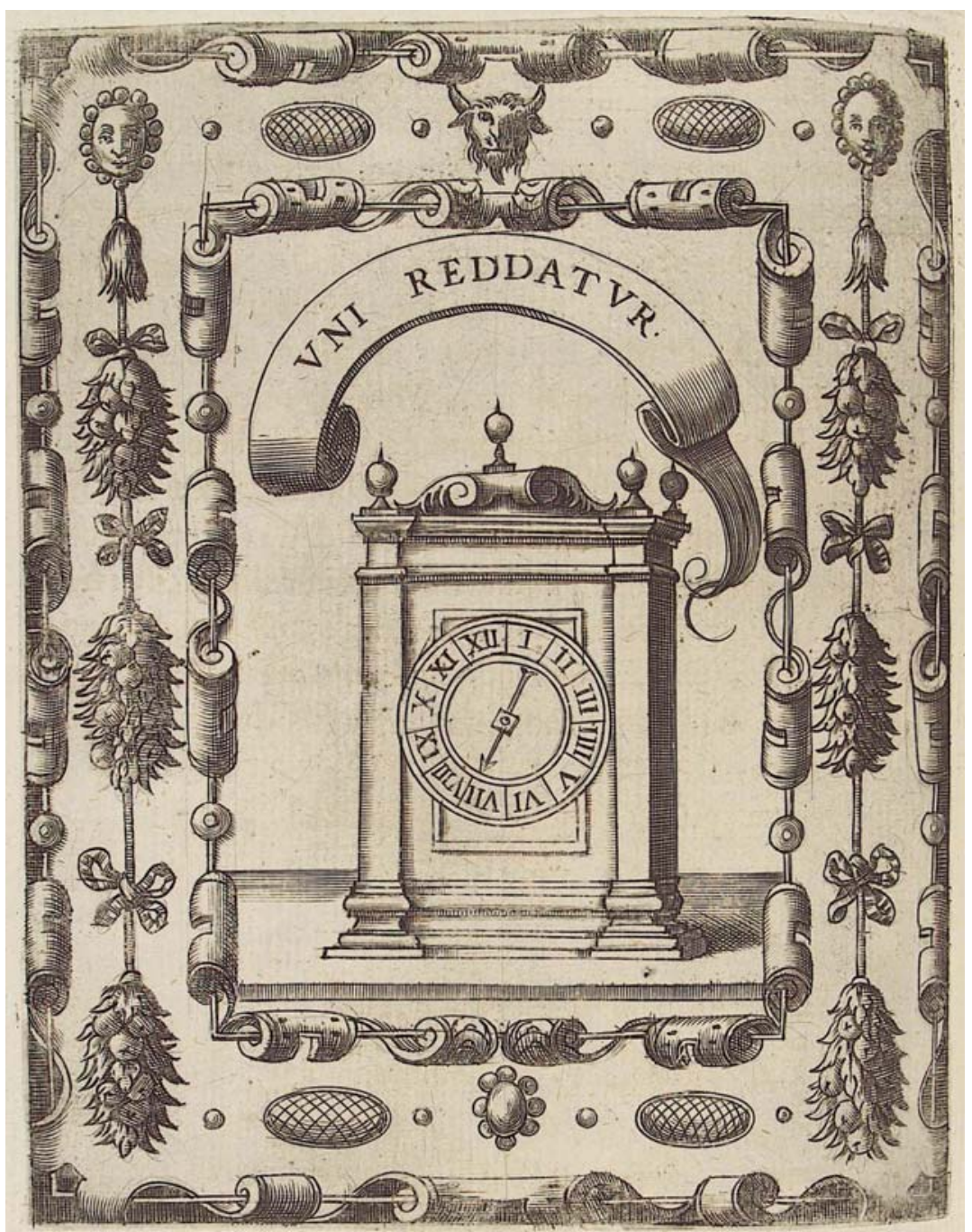

Fig. 17. Diego Saavedra Fajardo. Idea de un Príncipe Político Cristiano. Empresa 57. Uni reddatur

Pero, junto a este planteamiento común, el predicador reflexiona sobre determinadas cualidades que considera específicas para un Consejo concreto, y sobre las que insiste de manera particular. Así, es perceptible la especial preocupación de Barcia por el valor de la unidad cuando se dirige al Consejo de Castilla. En un sermón predicado en San Gil en 1691, el milagro de la resurrección de Lázaro ${ }^{106}$ (Jn 11, 1-44) le sirve para aleccionar a sus miembros sobre este punto, valiéndose de diversas imágenes emblemáticas tomadas de

106. Despertador Christiano Quadragessimal de Sermones Doctrinales, t. II, 323-332. 
Picinelli. ${ }^{107}$ Compara a los consejeros con las abejas, en las que todo su desvelo es trabajar por el bien común (Labor omnibus unus); con la granada que mantiene sus granos unidos, como símbolo de la concordia; y con los relojes, cuya misión es señalar una misma hora (Tendimus una), al igual que ocurre con los consejeros, que no deben atender sino a un mismo fin para juzgar y gobernar. Consecuencia de la unidad y concordia entre los miembros del Consejo será la fortaleza y firme resolución con que adoptarán sus acuerdos, sin dejarse doblegar por presiones externas; por tal motivo, los ministros deben ser leones cuyo comportamiento se asemeje al del cristal que, siendo transparente, antes prefiere quebrarse que doblarse (Frangitur, non flectitur). Unidad, concordia, fortaleza y resolución son en consecuencia las cualidades que propugna Barcia para el Consejo de Castilla.

En cuanto al Consejo de Indias, Barcia recuerda que Dios ha concedido a España el Nuevo Mundo para salvación de aquellas almas, de manera que es necesario plantar, conservar y propagar la fe. ${ }^{108}$ Por tal motivo, el Consejo debe ser consciente de su responsabilidad en la elección de ministros seculares y eclesiásticos destinados al gobierno de aquel territorio, escogiendo para tales puestos a personas sobre las que no recaiga la mínima sospecha acerca de su rectitud de intenciones, dado que «van muy lejos, y si tienen algún defecto, no es fácil enmendarlos». Y pone diversos ejemplos extraídos nuevamente de Picinelli, como el de la antorcha que, ya puesta hacia arriba o hacia abajo, mantiene siempre su llama dirigida hacia el cielo (Semper sursum), la rueda cuyos radios convergen en el centro (Spectamus ad unum), la aguja de marear, que siempre señala hacia el norte para manifestar el rumbo que conduce al puerto (Undequaque ad idem), o la constelación de la cruz austral que muestra el camino a los navegantes en el Polo Sur (Novum pandit iter). ${ }^{109} \mathrm{El}$ mismo comportamiento ejemplar deberán manifestar los ministros que van a las Indias, guiándose en todo momento por la cruz de Cristo en su labor de servicio a los demás.

En los sermones predicados al Consejo de Hacienda, se hace evidente en Barcia su empeño en denunciar la codicia como principal defecto. ${ }^{110}$ Afirma que hay muchos que aspiran a los cargos de Hacienda solo por satisfacer su ambición, adueñándose ilícitamente de las riquezas y arruinando a los más pobres. Comportamiento reprobable, pues el ministro de Hacienda deberá atender al beneficio público sin interponerse en la lluvia de bienes que Dios comunica a España; y, siguiendo a Picinelli, propone como símbolo elocuente de esta conducta ingrata al fuego, cuya voraz llama destruye aquella materia

107. Picinelli, Mundus Symbolicus, Libro VIII, cap. I, n. ${ }^{\circ} 23$; Libro XXI, cap. IX, n. ${ }^{\circ}$ 69; y Libro XII, cap. XXXVI, n. ${ }^{\circ} 330$.

108. Despertador Christiano Quadragessimal de Sermones Doctrinales, t. I, 227-235 y 283-291.

109. PICInelli, Mundus Symbolicus, Libro II, cap. III , n. ${ }^{\circ}$ 102; Libro XXIV, cap. XII, n. ${ }^{\circ} 86$; y Libro XII, cap. XxIV, n. ${ }^{\circ} 181$.

110. Despertador Christiano Quadragessimal de Sermones Doctrinales, t. I, 291-299. 
gracias a la cual subsiste (Alentem devorat). ${ }^{111} \mathrm{Al}$ igual que el fuego acaba por destruirse a sí mismo, también el ministro que se apropie de los bienes comunes acabará encontrando su perdición a causa de su codicia.

Si ambición y codicia son los vicios que critica en el Consejo de Hacienda, en el de la Inquisición son fama y vanidad, aspiraciones terrenales que no podrán confortar al alma, pues esta tan solo encuentra alivio y descanso en Dios. ${ }^{112}$ «¿Qué fin tenéis en amar y buscar la nada, la vanidad?», espeta a sus miembros Barcia; si el fin al que aspira el alma es la salvación, desdichados son los cargos y honores que no conducen a ella, sino que la estorban. Bien lo expresó a su juicio el benedictino Benedictus Van Haeften en su Schola Cordis, libro de meditación dirigido a las almas contemplativas para promover el culto y la devoción al Sagrado Corazón de Jesús. ${ }^{113}$ En concreto, en la Lección II del Libro II que lleva por mote Cordis Vanitas (Vanidad del corazón), acompañado de una cita del Eclesiástico 16, 23: Qui minoratur corde, cogitat inania (Quien se apoca en el corazón, piensa cosas vanas). El grabado muestra al amor divino que señala con rostro cariacontecido hacia el alma que, seducida por los bienes terrenales, llena de vanidades el corazón que sostiene en su mano derecha, labor encomendada a un demonio que por medio de un fuelle introduce el aire de aquellos objetos que no son sino ejemplos del poder, la riqueza y los deleites terrenales ${ }^{114}$ [Fig. 18]. Enfermo está el corazón que se ocupa en las vanidades y honores de este mundo; por ello, otorgue el Señor a los miembros del Consejo un corazón sano y amante de Dios que viva en la gracia divina, concluye el predicador.

Abandonada la búsqueda de honras y vanidades, los miembros de este santo tribunal deberán velar por la defensa de la Iglesia, desterrando de ella los errores en materia de fe. Sigan para ello el ejemplo de santo Tomás, aconseja Barcia en la solemne celebración de su festividad, pues es su doctrina luz clara que ilumina. ${ }^{115}$ Por eso fue símbolo del Doctor Angélico el unicornio, amado por todos los animales, debido a que la punta de su frente posee una virtud

111. PiCinelli, Mundus Symbolicus, Libro II, cap. I, n. ${ }^{\circ} 18$.

112. Despertador Christiano Quadragessimal de Sermones Doctrinales, t. II, 169-177.

113. Editada en Amberes en 1623, Schola Cordis establece la más firme doctrina del corazón basada en la praxis y el ejercicio de la perfección espiritual del alma humana. Por ello, el argumento de la obra (estructurada en varios libros y lecciones ilustradas con emblemas que protagonizan el alma humana y el Amor Divino en forma de niños), muestra el proceso mediante el cual el alma, tras endurecer su corazón y alejarse del Amor Divino, alcanza la iluminación que le permite el progreso espiritual y la perfección, que es la unión de espíritu y voluntad con Cristo. SANTIAgo SEBASTIÁN: Contrarreforma y Barroco: lecturas iconográficas e iconológicas, Alianza, Madrid, 1981, 322-327.

114. Benedictus Van Haeften: Schola Cordis sive a Deo Cordis, Antverpiae, Apud Ioannem Mevrsivm, et Hieronimvm Verdvssivm, 1635, 96-103. En su reflexión sobre la vanidad de los bienes terrenales, van Haeften recoge diversas citas del Eclesiastés y de los Salmos, y se remite asimismo a autores como Plinio, Séneca, san Juan Crisóstomo, san Anselmo y san Agustín. Además de la edición original, hemos consultado también la traducción Escuela del corazón, que escribió en lengua latina el R. P. D. Benito Haeften, de la Orden de San Benito; y ha vertido en la castellana Fr. Diego de Mecolaeta de la misma Orden, Barcelona, 1864, 81-86.

115. Despertador Christiano Santoral, de varios sermones de Santos, 54-62. 


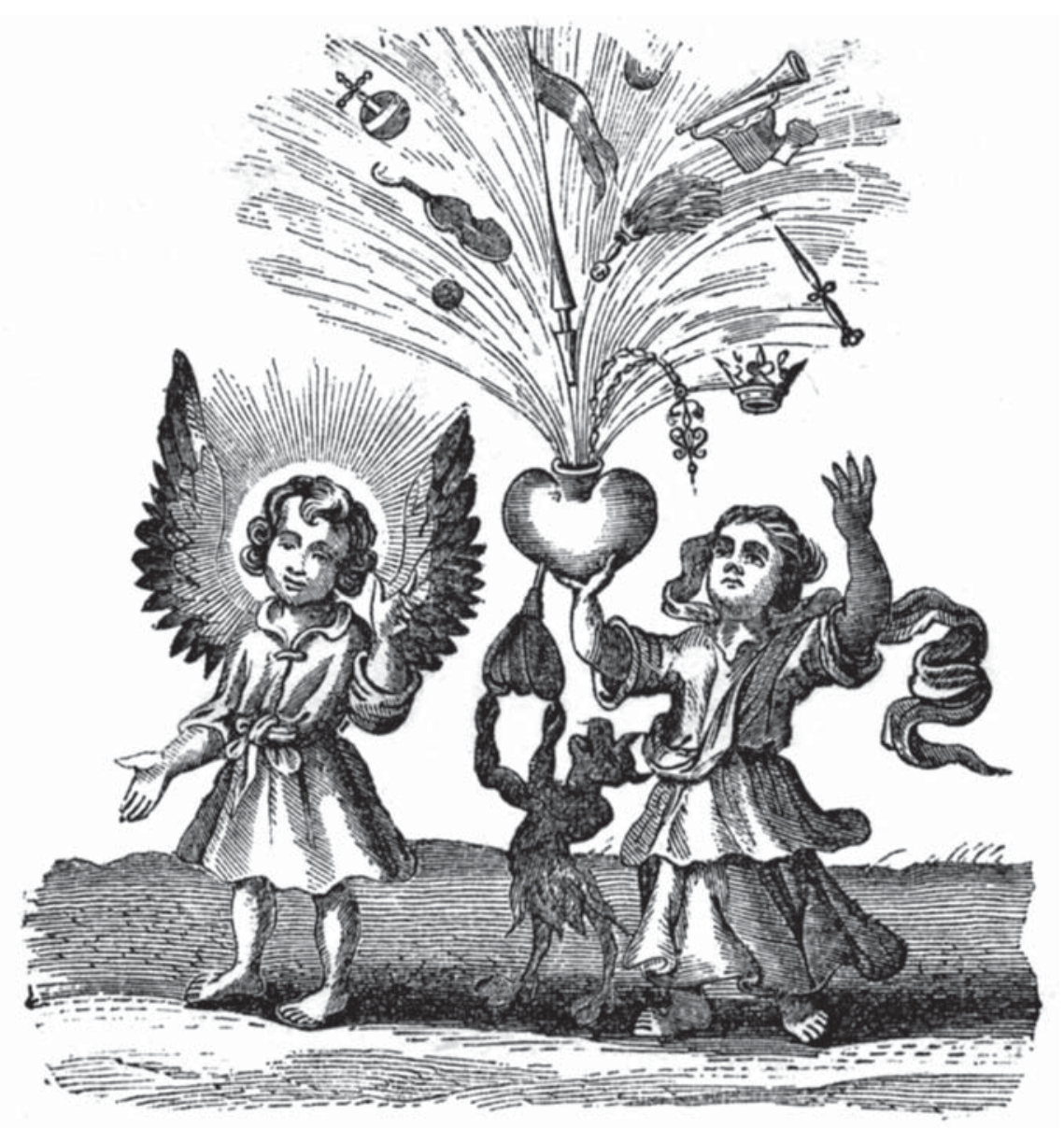

Fig. 18. Benedictus Van Haeften. Schola Cordis. Cordis Vanitas

natural por la que, tocando las aguas, las preserva de cualquier veneno que hayan contraído por el contagio de las víboras y otras criaturas ponzoñosas; conociendo esto los demás animales, esperan la llegada del unicornio para que, reclinando sobre las aguas la punta de su frente, pierda el veneno su fuerza, y puedan todos beber sin temer por sus vidas. A esta propiedad alude Picinelli en su Mundus Symbolicus -fuente de la que se sirve Barcia-, para quien el unicornio es imagen de santo Tomás y del acierto de quien bebe en su doctrina (Hoc duce tuti). ${ }^{116}$ De igual forma, no habrá en los consejeros de la Inquisición peligro de errar ni riesgo de venenosos errores, si siguen la doctrina de santo Tomás, asevera Barcia.

116. Picinelli, Mundus Symbolicus, Libro V, cap. xxxiv, n. 544. 


\section{Epílogo}

El 1 de noviembre de 1689, Carlos II asistía en la Capilla Real del Alcázar a la solemne función de Todos los Santos, con sermón predicado desde el púlpito por José Barcia. En su homilía, aseguraba al monarca que los santos eran el auxilio y ejemplo que ponía la Iglesia para seguir el camino de la virtud y alcanzar así la eterna felicidad; espejo en el que mirarse y nave en la que surcar el peligroso mar de este mundo para entrar «en aquel Reino dichoso, en aquel palacio del Rey de Reyes de Majestad infinita». Y trazaba a continuación el plan mediante el cual lograría gozar de la gloria de los santos, una normativa que se convierte en apretada síntesis de toda su predicación a Carlos II. El rey debía distinguirse por virtudes propias de reyes, pues no eran suficientes para su salvación virtudes de súbditos; y para ello tenía que cumplir con las obligaciones propias de su oficio y estado, atendiendo a los cuidados del reino: salvaguardar la religión, procurar el bien común y atender a la caridad; trabajar por conservar la paz y la unidad; defender la verdad y la justicia desoyendo las voces de la adulación y la lisonja; y, lo que era irrenunciable, apartar la vista de las honras, riquezas y vanidades del mundo, para vivir y morir en gracia de Dios. ${ }^{117}$

Once años más tarde, el 1 de noviembre de 1700, a los 39 años de edad y tras 42 días de agonía, el rey de todas las Españas, el último descendiente de la rama española de los Habsburgo, expiraba en su lecho de muerte. ${ }^{118}$ Había llegado el momento de comprobar si había puesto en práctica las exhortaciones de quien ya cinco años antes abandonaba la silla episcopal gaditana para gozar de mejor asiento junto a la Divina Majestad.

117. Despertador Christiano Santoral, de varios sermones de Santos, 307-315.

118. Sobre la muerte del monarca y las exequias carolinas en los dominios hispánicos, véase VíctoR Mínguez Cornelles: «Imperio y muerte. Las exequias de Carlos II y el fin de la dinastía a ambas orillas del Atlántico», Arte, poder e identidad en Iberoamérica. De los virreinatos a la construcción nacional (ed. Inmaculada Rodríguez Moya), Universitat Jaume I, Castelló de la Plana, 2008, 17-51. 